Research article

\title{
Impact of invasive alien plants on native plant communities and Natura 2000 habitats: State of the art, gap analysis and perspectives in Italy
}

Lorenzo Lazzaro a,b,*, Rossano Bolpagni ${ }^{\text {a,c }}$, Gabriella Buffa ${ }^{\text {a,d }}$, Rodolfo Gentili ${ }^{\text {a,e }}$, Michele Lonati $^{a, f}$, Adriano Stinca ${ }^{\text {a,g }}$, Alicia Teresa Rosario Acosta ${ }^{a, h}$, Michele Adorni ${ }^{a, i}$, Michele Aleffi $^{\mathrm{a}, \mathrm{j}}$, Marina Allegrezza ${ }^{\mathrm{a}, \mathrm{k}}$, Claudia Angiolini ${ }^{\mathrm{a}, \mathrm{l}}$, Silvia Assini ${ }^{\mathrm{a}, \mathrm{m}}$, Simonetta Bagella ${ }^{\mathrm{a}, \mathrm{n}}$, Gianmaria Bonari ${ }^{\mathrm{a}, \mathrm{o}}$, Maurizio Bovio ${ }^{\mathrm{a}, \mathrm{p}}$, Francesco Bracco ${ }^{\mathrm{a}, \mathrm{m}}$, Giuseppe Brundu $^{\mathrm{a}, \mathrm{q}}$, Marco Caccianiga ${ }^{\mathrm{a}, \mathrm{r}}$, Lucilla Carnevali ${ }^{\mathrm{s}}$, Valter Di Cecco $^{\mathrm{a}, \mathrm{t}}$, Simona Ceschin ${ }^{\text {a,h }}$, Giampiero Ciaschetti ${ }^{\text {a, }}$, Annalena Cogoni ${ }^{\text {a,v }}$, Bruno Foggi ${ }^{\text {a,b }}$, Anna Rita Frattaroli ${ }^{a, t}$, Piero Genovesi ${ }^{\mathrm{s}}$, Daniela Gigante ${ }^{\mathrm{a}, \mathrm{w}}$, Fernando Lucchese ${ }^{\mathrm{a}, \mathrm{h}}$, Andrea Mainetti $^{\mathrm{a}, \mathrm{f}}$, Mauro Mariotti ${ }^{\mathrm{a}, \mathrm{x}}$, Pietro Minissale ${ }^{\mathrm{a}, \mathrm{y}}$, Bruno Paura ${ }^{\mathrm{a}, \mathrm{z}}$, Mauro Pellizzari ${ }^{\mathrm{a} \text {, aa }}$, Enrico Vito Perrino $^{\mathrm{a}, \mathrm{ab}}$, Gianfranco Pirone ${ }^{\mathrm{a}, \mathrm{t}}$, Laura Poggio ${ }^{\mathrm{a}, \mathrm{ac}}$, Livio Poldini ${ }^{\mathrm{a}, \mathrm{ad}}$, Silvia Poponessi ${ }^{\text {a, ae }}$, Irene Prisco ${ }^{\text {a, }}$, Filippo Prosser ${ }^{\text {a, af }}$, Marta Puglisi ${ }^{\text {a,y }}$, Leonardo Rosati ${ }^{\text {a, ag }}$, Alberto Selvaggi $^{\text {a, ah }}$, Lucio Sottovia ${ }^{\text {a, ai }}$, Giovanni Spampinato ${ }^{\text {a, aj }}$, Angela Stanisci ${ }^{\text {a, ak }}$, Roberto Venanzoni $^{\text {a, ae }}$, Daniele Viciani ${ }^{\text {a,b }}$, Marisa Vidali ${ }^{\text {a, ad }}$, Mariacristina Villani ${ }^{a, a l}$, Lorenzo Lastrucci ${ }^{\text {a, am }}$

${ }^{a}$ Italian Society for Vegetation Science (SISV), Via Scopoli 22-24, I-27100, Pavia, Italy

${ }^{\mathrm{b}}$ Department of Biology, University of Florence, Via G. La Pira 4, I-50121, Firenze, Italy

${ }^{\mathrm{c}}$ Department of Chemistry, Life Sciences and Environmental Sustainability, University of Parma, Parco Area delle Scienze 11/a, I-43124, Parma, Italy

d Department of Environmental Sciences, Informatics and Statistics, Ca' Foscari University of Venice, Via Torino 155, I-30172, Venezia, Italy

${ }^{\mathrm{e}}$ Department of Earth and Environmental Sciences, University of Milan-Bicocca, Piazza della Scienza 1, I-20126, Milano, Italy

${ }^{\mathrm{f}}$ Department of Agricultural, Forest and Food Sciences, University of Torino, Largo Paolo Braccini 2, I-10095, Grugliasco, Italy

${ }^{g}$ Department of Environmental, Biological and Pharmaceutical Sciences and Technologies, University of Campania "Luigi Vanvitelli", Via A. Vivaldi 43, I-81100, Caserta, Italy

${ }^{\mathrm{h}}$ Department of Sciences, University of Roma Tre, Viale G. Marconi 446, I-00146, Roma, Italy

${ }^{i}$ Via degli Alpini 7, I-43037, Lesignano de' Bagni (PR), Italy

${ }^{\mathrm{j}}$ School of Biosciences and Veterinary Medicine, Plant Diversity \& Ecosystems Management Unit, Bryology Laboratory \& Herbarium, University of Camerino, Via Pontoni 5, I-62032, Camerino (MC), Italy

${ }^{\mathrm{k}}$ Department of Agricultural, Food and Environmental Sciences, Marche Polytechnic University, Via Brecce Bianche, I-60131, Ancona, Italy

${ }^{1}$ Department of Life Sciences, Via P.A. Mattioli 4, I-53100, Siena, Italy

${ }^{\mathrm{m}}$ Department of Earth and Environmental Sciences, University of Pavia, Via S. Epifanio 14, I-27100, Pavia, Italy

${ }^{n}$ Department of Chemistry and Pharmacy, University of Sassari, Via Piandanna 4, I-07100, Sassari, Italy

${ }^{\circ}$ Faculty of Science and Technology, Free University of Bozen-Bolzano, Piazza Universita, 5, I-39100, Bozen-Bolzano, Italy

" Comitato Scientifico, Museo Regionale di Scienze Naturali “Efisio Noussan”, Loc. Tache, I-11010, Saint-Pierre (AO), Italy

${ }^{\mathrm{q}}$ Department of Agriculture, University of Sassari, Viale Italia 39, I-07100, Sassari, Italy

${ }^{\mathrm{r}}$ Department of Biosciences, University of Milan, Via Celoria 26, I-20133, Milano, Italy

${ }^{\mathrm{s}}$ Istituto Superiore per la Protezione e la Ricerca Ambientale (ISPRA), Via V. Brancati 60, I-00144, Roma, Italy

${ }^{\mathrm{t}}$ Department of Life, Health \& Environmental Sciences, University of L'Aquila, Piazzale Salvatore Tommasi 1, I-67100, L'Aquila, Italy

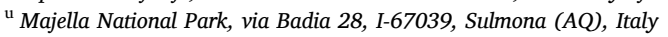

${ }^{\mathrm{v}}$ Department of Life and Environmental Sciences, Botany section, University of Cagliari, V.le S. Ignazio 13, I-09123, Cagliari, Italy

${ }^{\mathrm{w}}$ Department of Agricultural, Food and Environmental Sciences, University of Perugia, Borgo XX giugno 74, I-06121, Perugia, Italy

${ }^{\mathrm{x}}$ Department of Earth, Environment and Life Sciences, University of Genova, Corso Europa 26, I-16132, Genova, Italy

${ }^{y}$ Department of Biological, Geological and Environmental Sciences, University of Catania, Via A. Longo 19, I-95125, Catania, Italy

${ }^{\mathrm{z}}$ Department of Agriculture, Environment and Food Sciences, via De Sanctis snc, I-86100, Campobasso, Italy

${ }^{\text {aa }}$ Istituto Comprensivo "Bentivoglio", Via Salvo D'Acquisto 5/7, I-44028, Poggio Renatico (FE), Italy

${ }^{\text {ab }}$ CIHEAM, Mediterranean Agronomic Institute of Bari, Via Ceglie 9, I-70010, Valenzano (BA), Italy

${ }^{\text {ac }}$ Scientific Research and Biodiversity Service, Gran Paradiso National Park, Fraz. Valnontey 44, I-11012, Cogne (AO), Italy

\footnotetext{
* Corresponding author. Via G. La Pira 4, I-50121, Firenze, Italy.

E-mail address: lorenzo.lazzaro@unifi.it (L. Lazzaro).
} 
${ }^{\text {ad }}$ Department of Life Sciences, University of Trieste, Via L. Gorgieri 5, I-34127, Trieste, Italy

${ }^{\text {ae }}$ Department of Chemistry, Biology and Biotechnology, University of Perugia, Polo Didattico, via del Giochetto 6, Ed. A, I-06126 Perugia Italy

${ }^{\text {af }}$ Fondazione Museo Civico di Rovereto, Largo S. Caterina 41, I-38068, Rovereto (TN), Italy

${ }^{\mathrm{ag}}$ School of Agricultural, Forestry, Food and Environmental Sciences, University of Basilicata, via dell'Ateneo Lucano 10, I-85100, Potenza, Italy

${ }^{\text {ah }}$ Istituto per le Piante da Legno e l'Ambiente, Corso Casale 476, I-10132, Torino, Italy

${ }^{\text {ai }}$ Ufficio Biodiversità e Rete Natura 2000, Provincia Autonoma di Trento, Via R. Guardini 75, I-38121, Trento, Italy

aj Department of Agriculture, Mediterranean University of Reggio Calabria, loc. Feo di Vito, I-89122, Reggio Calabria, Italy

${ }^{\mathrm{ak}}$ Department of Bioscience and Territory, University of Molise, via Duca degli Abruzzi s.n.c., I-86039, Termoli, Italy

al Botanical Garden of Padua, University of Padua, Via Orto Botanico 15, I-35121. Padova, Italy

am University Museum System, Natural History Museum of the University of Florence, Botany, Via G. La Pira 4, I-50121, Florence, Italy

\section{A R T I C L E I N F O}

\section{Keywords:}

Competition

Ecological impact

Expert survey

Impact mechanism

Impact outcome

Natura 2000 network

\begin{abstract}
A B S T R A C T
Invasive alien plants are a major threat to biodiversity and they contribute to the unfavourable conservation status of habitats of interest to the European Community. In order to favour implementation of European Union Regulation no. 1143/2014 on invasive alien species, the Italian Society of Vegetation Science carried out a large survey led by a task force of 49 contributors with expertise in vegetation across all the Italian administrative regions. The survey summed up the knowledge on impact mechanisms of invasive alien plants in Italy and their outcomes on plant communities and the EU habitats of Community Interest, in accordance with Directive no. 92/ 43/EEC. The survey covered 241 alien plant species reported as having deleterious ecological impacts. The data collected illustrate the current state of the art, highlight the main gaps in knowledge, and suggest topics to be further investigated. In particular, the survey underlined competition as being the main mechanism of ecological impact on plant communities and Natura 2000 habitats. Of the 241 species, only Ailanthus altissima was found to exert an ecological impact on plant communities and Natura 2000 habitats in all Italian regions; while a further 20 species impact up to ten out of the 20 Italian administrative regions. Our data indicate that 84 out of 132 Natura 2000 Habitats (64\%) are subjected to some degree of impact by invasive alien plants. Freshwater habitats and natural and semi-natural grassland formations were impacted by the highest number of alien species, followed by coastal sand dunes and inland dunes, and forests. Although not exhaustive, this research is the first example of nationwide evaluation of the ecological impacts of invasive alien plants on plant communities and Natura 2000 Habitats.
\end{abstract}

\section{Introduction}

Biological invasions are one of the most important drivers of biodiversity loss and ecosystem degradation worldwide (Seebens et al., 2017). The establishment and spread of invasive alien species (IAS) have affected multiple ecosystem processes, including community composition, biotic interactions, and functions and services (Vilà and Hulme, 2017). Furthermore, IAS can also impact important socio-economic assets, reducing the efficiency of natural resource exploitation, affecting infrastructure effectiveness, and imposing costly management efforts (Bacher et al., 2017). IAS are indeed one of the major drivers of changes in European habitats, and increase the probability of unfavourable conservation status of natural habitats (Maes, 2013), causing a general deterioration of biodiversity and the alteration of habitat structure and functions in plant communities (Pyšek et al., 2012; Gigante et al., 2018). Therefore, it is an urgent and complex goal in invasion biology to understand the mechanisms underlying biological invasions, one crucial to predicting habitat invasibility (i.e. susceptibility to invasions) and recognising community response to invasion in order to implement actions for the restoration and long-term management of invaded habitats.

Despite there being a general awareness of the effects of invasive alien plants (IAPs), in Europe there is still a lack of exhaustive works investigating the effects of IAPs on native plant communities and on the habitats of Community Interest listed in the Habitats Directive (Council Directive no. 92/43/EEC, hereafter N2000 habitats) (Guerra et al., 2018). The N2000 network proved to be crucial for preserving the EU's biodiversity, although there are increasing calls for improvements and adjustments (Trochet and Schmeller, 2013; Friedrichs et al., 2018). The importance of the N2000 network in tackling the risks posed by biological invasions was underlined by the European Commission in the $E U$ 2020 Biodiversity Strategy, and further emphasised in the recent EU 2030 Biodiversity Strategy. However, there is still no common approach for protecting the N2000 network, and its efficacy in decreasing the vulnerability to invasive alien species is in large part still unknown (Guerra et al., 2018; Mazaris and Katsanevakis, 2018). Data on the presence and impact of IAS on the N2000 network is crucial to counter their detrimental impacts, and of pivotal importance when considering the effects of climate change, which are likely to increase the uncertainty associated with IAS performance (Guerra et al., 2018). Indeed, protected areas and the N2000 network could become valuable tools to tackle the spread of invasive species, especially in the light of future climate change (Gallardo et al., 2017).

In Italy, research on IAPs has gained momentum in the last 20 years (Lazzaro et al., 2019). Celesti-Grapow et al. (2009) published the first comprehensive checklist, recently updated by Galasso et al. (2018a). Several national projects and studies have been carried out in the last ten years (e.g. Malavasi et al., 2018; Celesti-Grapow et al., 2016; Lazzaro et al., 2019). Nevertheless, scientific literature concerning the impacts of IAPs in Italy is still patchy and there are no data for some taxa and N2000 habitats.

In this context, the Italian Institute for Environmental Protection and Research (ISPRA) commissioned a project to collect information on the impacts of IAPs on biodiversity and on the N2000 network in Italy, as a part of a national program to support the implementation of Regulation (EU) $1143 / 2014$ on IAS funded by Ministry of the Environment and Preservation of Land and Sea. The study, designed and conducted by the Italian Society of Vegetation Science (SISV), had two main aims: develop of a check-list of alien-dominated plant communities in Italy (Viciani et al., 2020); and assess of the ecological impacts of IAPs on N2000 habitats in Italy. To achieve this second goal, we carried out a survey of the literature and of expert opinion that involved a large number of botanist members of SISV. Specifically, this survey aimed at i) verifying and listing IAPs known to affect native plant communities and N2000 habitats on a regional and a national scale, and ii) assessing the mechanism by which species make an impact and the possible impacts exerted (i.e. impact mechanisms and impact outcomes, respectively, according to Blackburn et al., 2014) and iii) determining whether impact outcomes are exerted on specific N2000 habitats. A supplementary aim was iv) to verify the presence of specific patterns of invasion in N2000 habitats, hypothesising that the life form and the time since its first introduction 
may play a pivotal role in the threat posed by IAPs to Italian N2000 habitats.

\section{Methods}

\subsection{Definitions and context}

We adopted the Regulation (EU) no. 1143/2014 definition of IAS as those "whose introduction or spread has been found to threaten or adversely impact upon biodiversity and related ecosystem services". We focused on Ecological impacts, defined as "a measurable change to the properties of an ecosystem by an alien species", considering only deleterious impacts, meant as "any impact that changes the environment in such a way as to reduce native biodiversity or alter ecosystem function to the detriment of the incumbent native species" (Blackburn et al., 2014). We included both natural and semi-natural ecosystems, considering only impacts affecting the native biota and/or ecosystem processes. Conversely, we did not consider either impacts on native species at the individual or population level, or any effect on human society (thus excluding any economic/social and health effects of IAPs).

We adopted the impact scheme of the Global Invasive Species Database (GISD, 2020), as described in Blackburn et al. (2014), taking into account all possible impact mechanisms identified by the scheme, and all the ecological impact outcomes at the ecosystem/habitat level (see Table 1). The nomenclature of IAPs follows Galasso et al. (2018a). As the assessment of the effects of IAPs on habitats of Community interest made up a pivotal part of our data collection, to define the habitats we followed the "Italian Interpretation Manual of the 92/43/EEC Habitats Directive" (Biondi et al., 2009) and the Interpretation manual of European Union EU28 (European Commission, 2013).

\subsection{Survey strategy}

Our evaluation of the current impact outcomes of IAPs in Italy was based on a survey of the literature and expert opinion. The working group was composed of 49 members of the SISV (the co-authors of the present work - mainly technicians or academic botanists, with expertise in vegetation science, N2000 habitats and IAPs), who provided data and their knowledge of the situation at the local (regional) level or regarding specific IAPs.

Table 1

Impact mechanisms and outcomes adopted in the survey of Italian IAPs. Each mechanism listed in the left column may result in one or more of the outcomes listed in the right column (Blackburn et al., 2014).

\begin{tabular}{ll}
\hline Impact mechanism & $\begin{array}{l}\text { Impact outcomes exerted at the ecosystem/habitat } \\
\text { level }\end{array}$ \\
\hline Competition & $\begin{array}{l}\text { Modification of hydrology/water regulation, } \\
\text { purification and quality/soil moisture }\end{array}$ \\
Predation & Primary production alteration \\
Hybridization & Modification of nutrient pool and fluxes \\
Disease transmission & Modification of natural benthic communities \\
Parasitism & Reduction in native biodiversity \\
Poisoning/Toxicity & Unspecified ecosystem modification \\
Bio-fouling & Habitat degradation \\
Grazing/Herbivory/ & \\
Browsing & Habitat or refugia replacement/loss \\
Rooting/Digging & Physical disturbance \\
Trampling & Modification of fire regime \\
Flammability & Modification of successional patterns \\
Interaction with other & Soil or sediment modification: erosion \\
invasive species & Soil or sediment modification: bioaccumulation \\
Others & Soil or sediment modification: modification of \\
& structure \\
& Soil or sediment modification: modification of pH, \\
& salinity or organic substances \\
& Other \\
\hline
\end{tabular}

We provided each expert with a spreadsheet template that included specific guidelines on the type of data required and how to fill in the spreadsheet (see Appendix 1). The template included an initial list of 184 IAPs established in Italy, taken from the National Alien Plant Species Data Base (Lazzaro et al., 2019). The contributors were asked to provide data on impact mechanisms and outcomes in their region in accordance with Blackburn et al. (2014), see Table 1. Particularly, for each species of the list, experts were asked to provide the following information: a) impact mechanism, b) impact outcomes, c) impact outcomes with specific reference to N2000 habitats, d) data source, specifying whether it originated from i) scientific literature, ii) technical reports or grey literature or iii) expert assessment, and e) the level of uncertainty of the data provided. In addition, contributors were encouraged to add to the list any further IAPs found to have an impact.

The survey strategy adopted in the study followed the framework of the consensus-building approach (see Vanderhoeven et al., 2017), in which several rounds of structured questionnaires, with subsequent aggregation of responses followed by feedback to the experts, are used to reduce inconsistencies among assessors. In our case, in a first round of evaluation, the contributors were asked to fill in the template individually, after reading the guidelines and the referenced documentation. Data from this preliminary collection (which ended on 2017 July 31) were aggregated and presented to all contributors during a two-day workshop (2017 October 16-17), to discuss possible shortcomings and identify knowledge gaps and dissimilarities in the data collection. After the workshop, we opened a second call (conclusion in 2017 December) to allow all the contributors to homogenize the data provided and overcome the shortcomings that emerged during the workshop.

\subsection{Data analyses}

\subsubsection{Breakdown of results on IAPs and impacts outcomes and mechanisms}

The data obtained on the impacts (mechanisms and outcomes) of IAPs on plant communities and N2000 habitats were merged into a single table. The data were cleaned and standardized, spelling mistakes were corrected and duplicate records were deleted. Data were organized to depict the overall patterns of IAP distribution across Italian regions, and to outline patterns of impact mechanisms and outcomes on native plant communities and N2000 habitats at species and administrative regions levels.

\subsubsection{Patterns of invasion on $\mathrm{N} 2000$ habitats}

With the aim of detecting specific trends of invasion, for all IAPs assessed as having an impact on N2000 habitats at a national level, we collected further data regarding a) the life form, b) the number of administrative regions colonized (according to Galasso et al., 2018a and subsequent updates, Galasso et al., 2018b, 2018c) and c) the date of the first introduction in Italy (information retrieved from literature and technical sources, see Appendix 2). However, although of paramount importance, data on the time of introduction is not entirely reliable, since it may correspond either to the date of the first introduction in botanical gardens or to the first detection in nature. Accordingly, we chose to reclassify neophytes into three main groups: 1) introduced between 1492 and 1800, 2) introduced between 1800 and 1950 and 3) introduced from 1950 to date (2020). This grouping (hereafter named introduction period) reflects the main changes in global human flows, passing from the age of geographical discoveries to the XIX century (1492-1799), from colonialism to the industrial revolution and the two world wars (1800-1950), and finally from the time of the economic boom to globalisation (1951-2020).

We excluded from the analysis all the species introduced before 1492 (archaeophytes) (only eight species among those exerting impacts on N2000 habitats: Abutilon theophrasti, Arundo donax, Cuscuta cesatiana, Cyperus esculentus, Cyperus serotinus, Isatis tinctoria subsp. tinctoria, Ricinus communis, Sorghum halepense), and Salvinia molesta, whose 
presence in Italy is doubtful.

We analysed impacts on single N2000 habitats (as indicated by the entire N2000 code, e.g. 1210) and then on macro-categories, as indicated by the first number of the $\mathrm{N} 2000$ code (e.g. 1: coastal habitats, 2: dune habitats and so on; see European Commission, 2013). To avoid possible biases due to the uneven number of habitats across administrative regions, the analyses were conducted at the national level (i.e. we used number of habitats and habitat macro-categories invaded by the species in Italy).

To investigate the correlation between the number of habitats, the number of macro-categories of habitats and the number of colonized administrative regions, we ran a correlation analysis for each introduction period, we calculated the pairwise Spearman's rank correlation coefficient (Spearman's $\rho$ ) and evaluated its significance by means of the asymptotic $t$ approximation.
Finally, we ran a series of generalized linear models (GLM) to study the effect of the introduction period and of the life form categories on the number of invaded N2000 habitats, the number of invaded N2000 habitat macro-categories, and the number of invaded administrative regions. Given the overdispersion of our data, we adopted a quasiPoisson distribution and evaluated the significance of the terms with an ANOVA table. All the analyses were conducted in $\mathrm{R}$ environment vers. 3.6.1 (R Core Team, 2019).

\section{Results}

\subsection{Breakdown of results on IAPs and impacts outcomes and mechanisms}

We collected data on 241 IAPs, 57 more than the 184 originally indicated in the template (see Appendix 2). Only a few species were
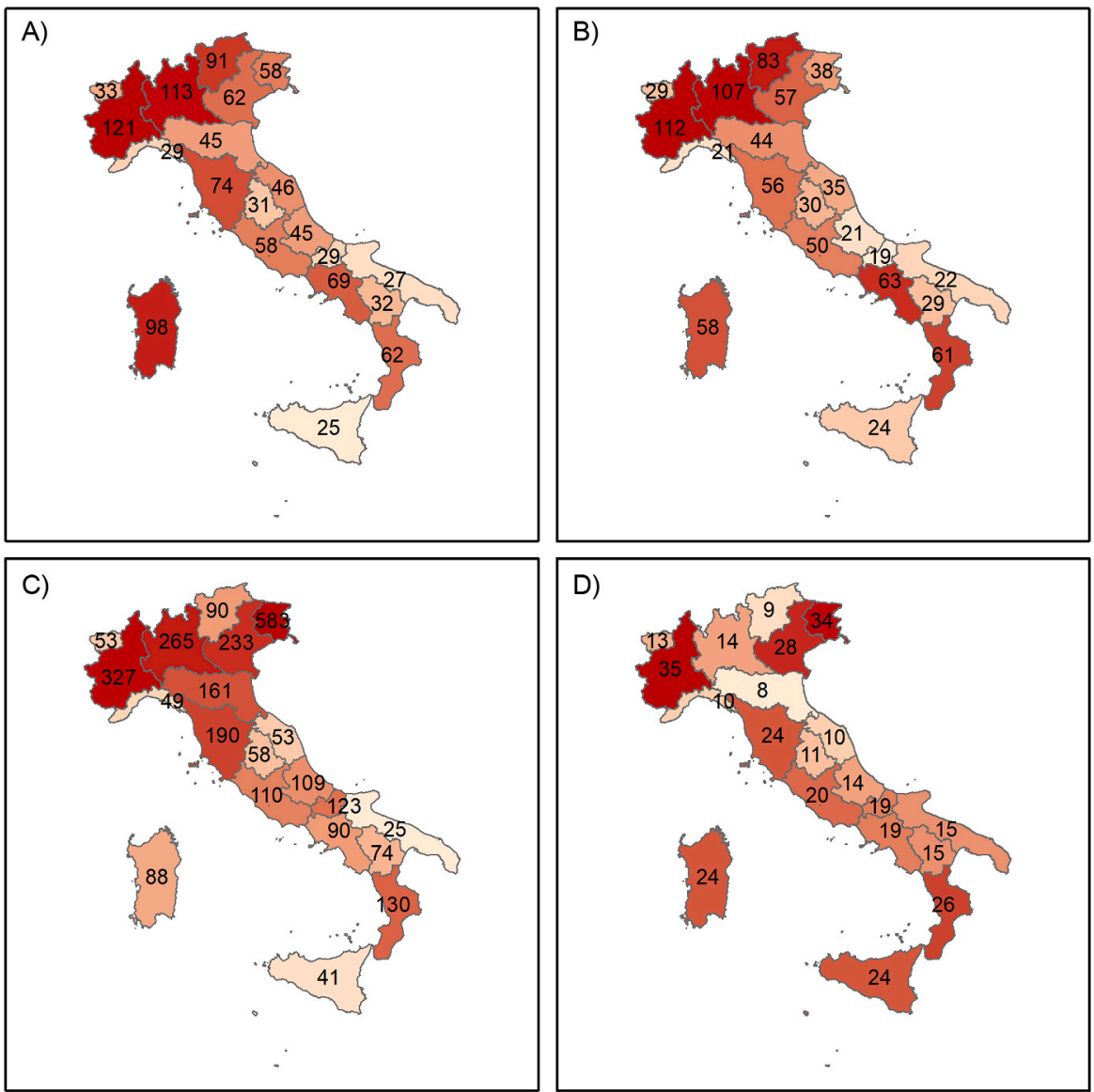

Fig. 1. Distribution of records on the impact of IAPs in Italy per administrative region. A) Distribution of records on impact mechanisms. B) Number of IAPs exerting any type of ecological impact. C) Distribution of records on impact outcomes on plant communities. D) Number of N2000 habitat types exposed to some degree of ecological impact by IAPs. E) Percentage of N2000 habitats exposed to some degree of ecological impact by IAPs on the total number of habitats harboured in the region.

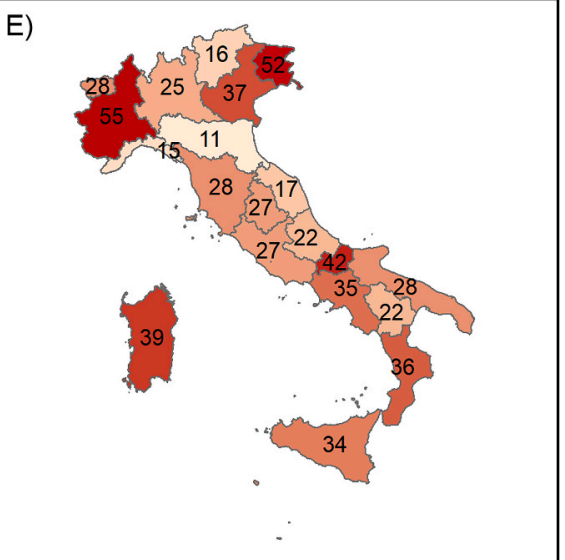


reported in a high number of administrative regions and by several contributors. In general, degree of knowledge varied substantially between regions, as shown by the variation in numbers of regional records on impact mechanisms and outcomes (Fig. 1A and C). The number of IAPs assessed as having an ecological impact (Fig. 1B) and the distribution of impacts on N2000 habitats (Fig. 1D), varied widely between administrative regions. Similarly, compared to the total number of habitats harboured in a given region, the percentage of those exposed to some degree of ecological impact was very variable, with Piedmont and Friuli-Venezia Giulia having more than half of the habitats impacted by IAPs, followed by Molise and Sardinia (Fig. 1E). Variability also characterized the relationship between species and their impact mechanisms and outcomes. Indeed, most IAPs had very few reports of mechanisms of impact-220 out of 241 species had less than five reports of impacts-while only a handful of species had a high number of records. A similar situation was found as far as impact outcomes are concerned: most of the species had very few reports and very few species had a high number of records (see Fig. 2). Of the impact mechanisms, "Competition" was the most frequent, being common to around $83 \%$ of reports, followed by "Unknown" mechanism (4\%), "Interaction with other invasive species" (4\%) and "Poisoning/toxicity" (3\%).

Ailanthus altissima, listed in all Italian administrative regions, was the species with the highest number of records of impact mechanisms. Competition was the main impact mechanism assigned to the species, followed by "Rooting/digging". Further species with a very high number of records, such as Senecio inaequidens, Robinia pseudoacacia, Helianthus tuberosus, Amorpha fruticosa and Sorghum halepense, were all assessed as invaders with a high degree of impact in many administrative regions (see Fig. 3A for main mechanisms of the first 23 species). Nevertheless, despite a high number of impact reports, most data-62\%-came from expert assessments that were not experimentally verified (Fig. 4 A). Only $25 \%$ of the reports were retrieved from the scientific literature and $13 \%$ from technical reports and grey literature.

Species most frequently recorded for impact outcomes differed from those most frequently recorded for impact mechanisms: Robinia pseudoacacia was the species with the highest number of impact outcome records, followed by Acacia saligna, Amorpha fruticosa, Arundo donax, Ailanthus altissima, Carpobrotus edulis, C. acinaciformis, Helianthus tuberosus, Senecio inaequidens, and Solidago gigantea (Fig. 3B). As with impact mechanisms, most of the records (78\%) were from expert assessments, while $13 \%$ were retrieved from technical reports and grey literature, and

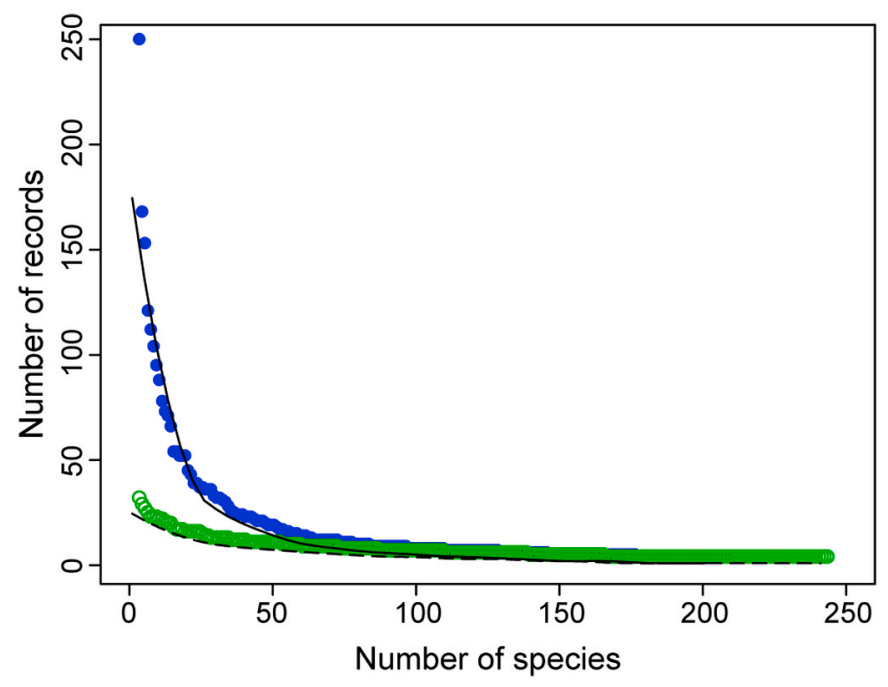

Fig. 2. Number of data collected regarding the presence of impact mechanism (empty green circles, dashed line) and impact outcomes (full blue circles, solid line) exerted by IAPs in Italy. (For interpretation of the references to colour in this figure legend, the reader is referred to the Web version of this article.) only $9 \%$ from the scientific literature (Fig. 4B).

Reduction in native biodiversity was by far the most reported outcome, followed by general habitat degradation, loss of habitat and refugia, and modification of successional patterns (Fig. 5A). The ranking of threats posed to N2000 habitats showed the same order. Indeed, a reduction in native biodiversity was cited for nearly all N2000 habitats present in Italy ( 81 out of 84 ), followed by the same outcomes named above (Fig. 5B).

Nonetheless, impacts were unevenly distributed, especially in terms of the number of IAPs impacting specific habitats, and less in terms of the number of administrative regions in which the target N2000 habitat is impacted (Fig. 6A-B). N2000 Habitat 3270 was by far the one impacted by the highest number of invasive species (79 species), followed by N2000 Habitat 6430. At the macro-category level, freshwater habitats (N2000 habitats 3xxx) and natural and semi-natural grassland formations (N2000 habitats 6xxx) were impacted by the highest number of alien species, followed by coastal sand dunes and inland dunes (N2000 habitats 2xxx), and forests (N2000 habitats 9xxx). In terms of the regional distribution of impacted habitats, freshwater habitats were generally affected in many regions, with coastal sand dunes, coastal and halophytic habitats (N2000 habitats $1 \mathrm{xxx}$ ) and forests also being frequently affected (Fig. 6 B).

\subsection{Patterns of invasion on $\mathrm{N} 2000$ habitats}

The 241 IAPs recorded in our survey included 167 neophytes invading the N2000 habitats; 29 species were introduced before 1800 , 84 between 1800 and 1950, and 54 after 1950 (Appendix 2). Therophytes (56 species) and phanerophytes (45) were the most frequent life forms, followed by hemicryptophytes (19), geophytes (17), chamaephytes (16), and hydrophytes (14). Ailanthus altissima, Robinia pseudoacacia, Senecio inaequidens, Amorpha fruticosa, and Carpobrotus edulis were the most frequent invaders both in N2000 habitats $(28,25,23,17$, 16 each respectively) and in habitat macro-categories $(7,7,8,6,5$ respectively), although with slightly different rankings (see Appendix 2). The number of habitats and that of habitat macro-categories invaded correlated strongly for all three periods (P value $<0.001$, see Table 2 ), although the correlation decreased slightly from the first introduction period (before 1800; $\rho=0.930$ ) to the last (from 1950 to date; $\rho=$ 0.845). Showing a more strongly decreasing trend, the number of regions colonised was significantly correlated with the number of habitats ( $\rho=0.523$, P value $=0.003)$ and macro-habitats invaded $(\rho=0.489$, P value $=0.007$ ) only for the first introduction period (before 1800); while no significant correlation was found for the other two introduction periods (Table 2).

Life form categories significantly affected the distribution of species in terms of number of invaded N2000 habitats and macro-habitats, as well as in terms of number of colonised administrative regions (Table 3). Overall, chamaephytes were the most widespread invaders, invading the highest number of habitats (and habitat macro-categories), followed by geophytes, phanerophytes and therophytes; hydrophytes were specific to a small number of habitats (Fig. 7A, C). On the other hand, therophytes had spread into the highest number of regions, together with geophytes (Fig. 7E). Introduction period strongly affected the number of habitats, of habitat macro-categories, and of administrative regions invaded (Table 3). Indeed, the longer a species had been introduced, the higher the number of invaded habitats, macro-habitats and administrative regions $(7 \mathrm{~B}, \mathrm{D}, \mathrm{F})$.

\section{Discussion}

Our data showed that the general impact of IAPs on native plant communities and N2000 habitats has still only been partially unravelled at the national level. Specifically, our study brought to light two main problems. One is that very few data are available on the mechanisms by which IAPs exert their impact. This lack greatly reduces our ability to 
A)

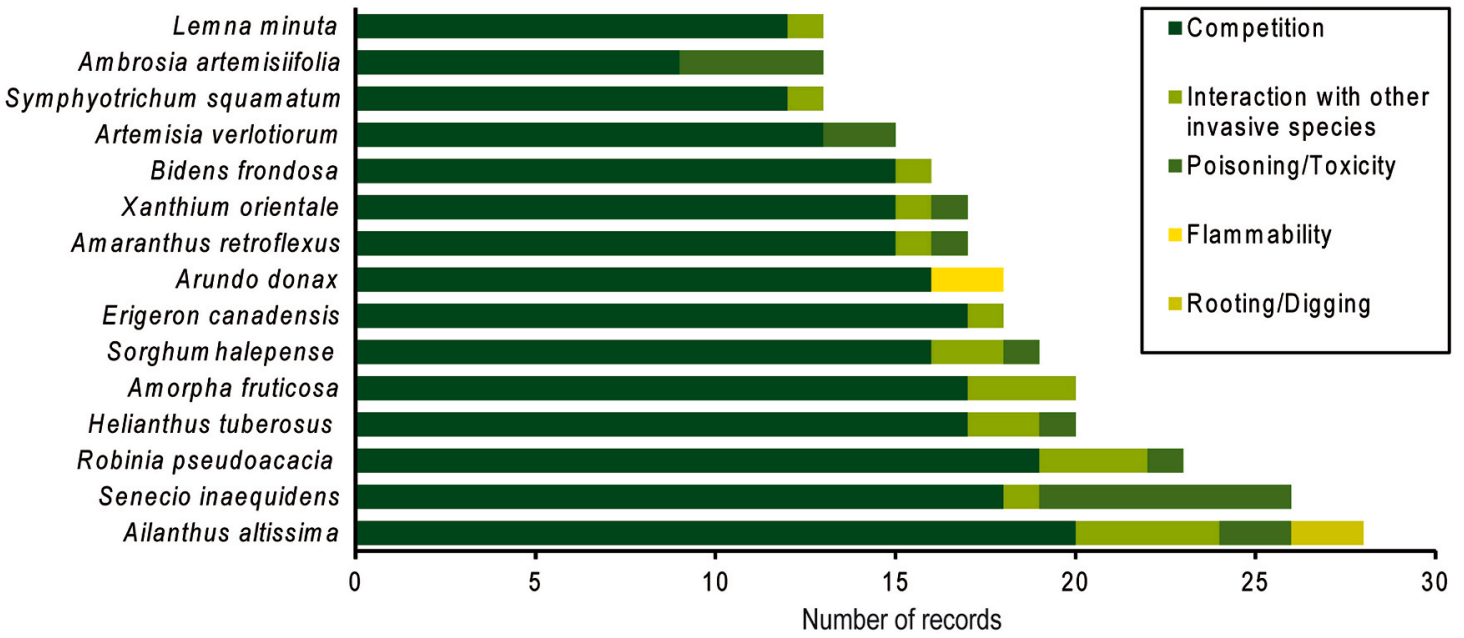

B)

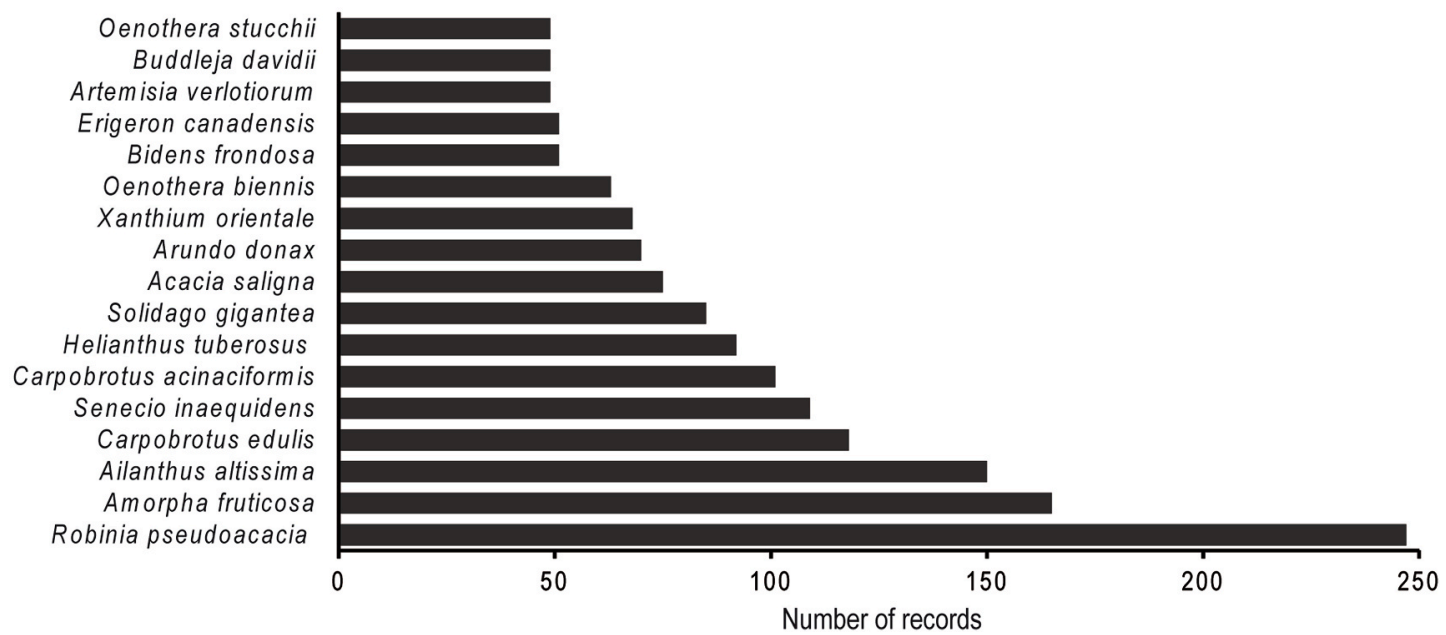

Fig. 3. A) Number of regional records with specific impact mechanisms for the first 23 IAPs. B) Number of total records of impact outcomes for the first 23 IAPs.

implement effective adaptive strategies to counteract the spread and the effects of IAPs. In addition to this, the data that are available are very unevenly distributed between regions, further reducing our capacity to understand the nation-wide effects of IAPs. Filling these gaps calls for an urgent nation-wide collaborative initiative with coordinated action programs and standard methodologies. The initiative would ideally be conducted under the auspices of ISPRA or of the Italian Ministry of the Environment and Preservation of Land and Sea, which provided funding and motivation for the present study. Also, the establishment of a national collaboration between numerous Italian research groups to participate in joint projects at the EU level (i.e. within EU LIFE programme or Horizon Europe, 2021-2027), or within national scientific societies like SISV or the Italian Botanical Society (SBI), is essential to complete the picture of alien species invasion in Italy.

The differences between the impacts recorded for different Italian regions are consistent with the findings of the main catalogues of alien plants in Italy (Galasso et al., 2018a; Celesti-Grapow et al., 2009). The highest number of records was observed in the largest and most densely populated regions (i.e. Lombardy, Piedmont, and Tuscany), where human-driven land cover changes like urbanization, industrialisation, road infrastructures, and agriculture, cause higher rates of introduction (McLean et al., 2017), thereby facilitating biological invasion. The intensification of agricultural use of land has been proven to play a crucial role in the introduction, establishment and spread of IAPs due to a decline in biodiversity caused by oversimplified landscape matrices (Walker et al., 2009; Buffa et al., 2018). This is especially true for lowland riverscapes which suffer from the deterioration of water, of sediments and of hydrological regimes (Bolpagni and Piotti, 2015; Bolpagni et al., 2013), situations that have been identified as common key factors driving the establishment and spread of IAPs in newly invaded areas (Aronson et al., 2017).

However, comparatively large and densely populated regions (e.g. Lazio, Emilia-Romagna) did not show the same degree of invasion. This difference could be the result of contrasting levels of awareness between the different administrative regions in Italy. A minority of regions have already adopted specific regulatory frameworks to address the issue of biological invasions (Brundu et al., 2020), while the other regions still pay little attention to this matter. Only Lombardy, Piedmont, Aosta Valley have a list of restricted IAPs, approved by regional laws, and working groups dedicated to IAPs. In Friuli-Venezia Giulia and Tuscany only few IAPs are considered in regional laws. Finally, Liguria has established a surveillance network and a permanent working group on IAS within the Italian-French ALIEM Project. To our knowledge, all the other Italian administrative regions lack a local regulatory framework on IAPs, even if the recent promulgation of legislative decree no. $230 / 2017$ calls for a comprehensive framework to tackle this issue. We are convinced that a decisive contribution to this matter would come from the establishment of a national list of invasive alien species of Member State (Italy) concern (see Art. 12 of Regulation (EU) no. 1143/2014), under the guidance of the Italian Ministry of the Environment and Preservation of Land and Sea. To this end, an important action aimed at the individuation of candidate species for the 

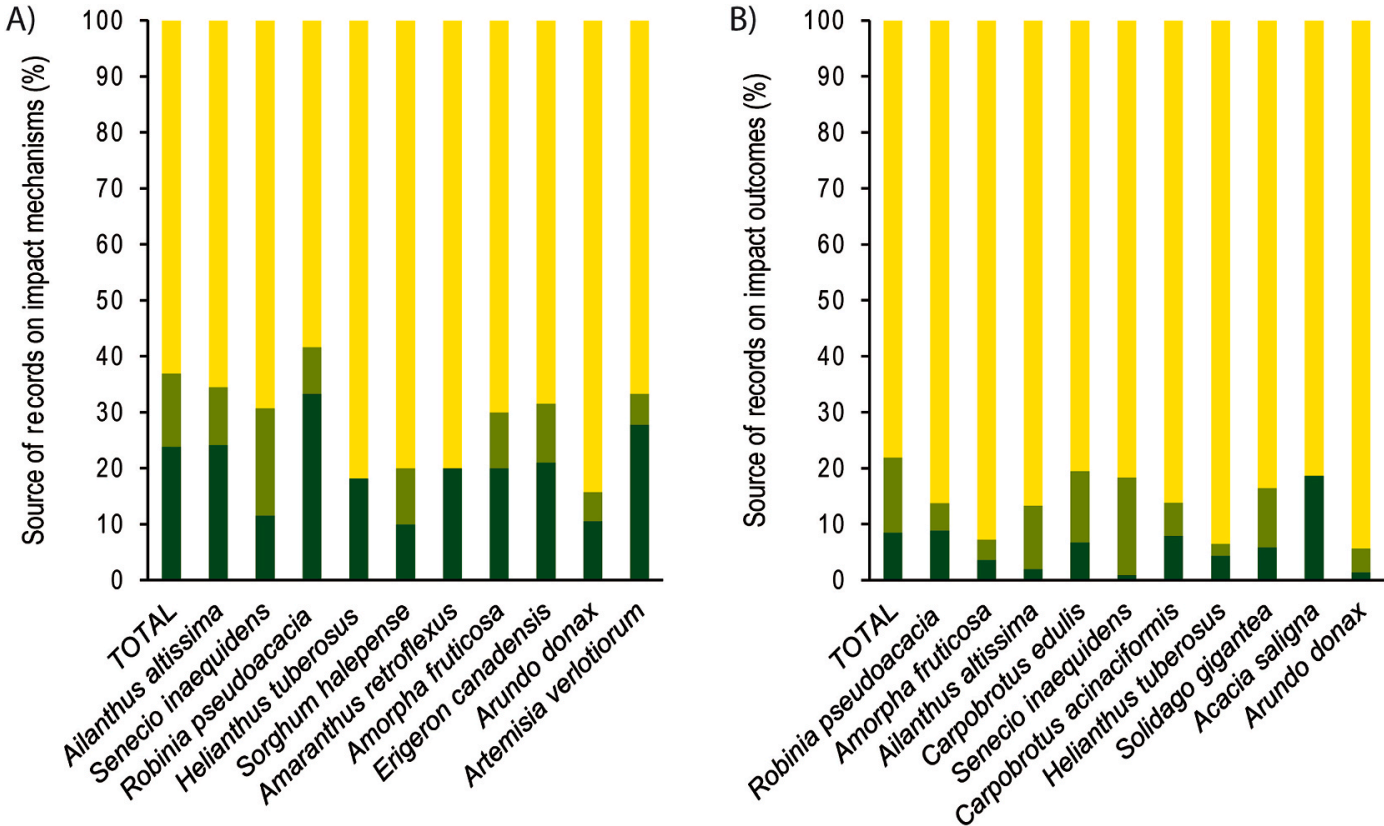

Literature data $\quad$ Technical report

Expert-based assessment

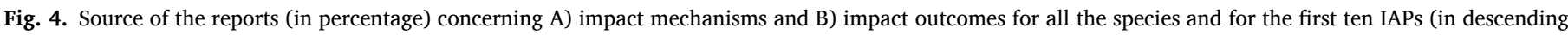
order by number of records).

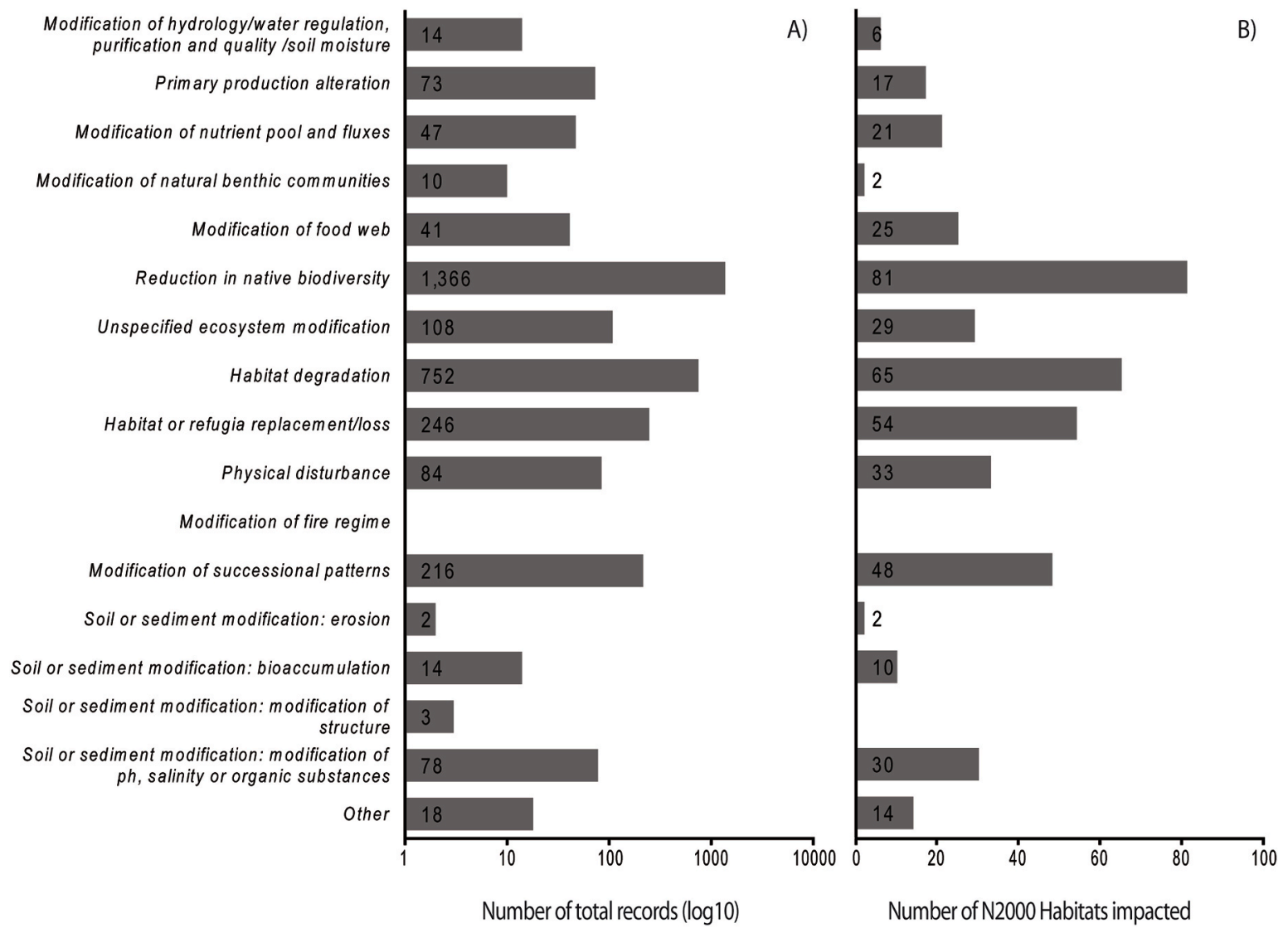

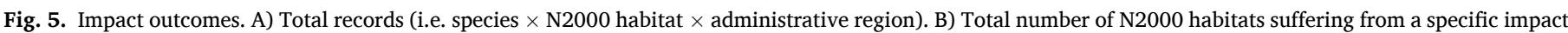
outcome (irrespective of species and administrative regions). 


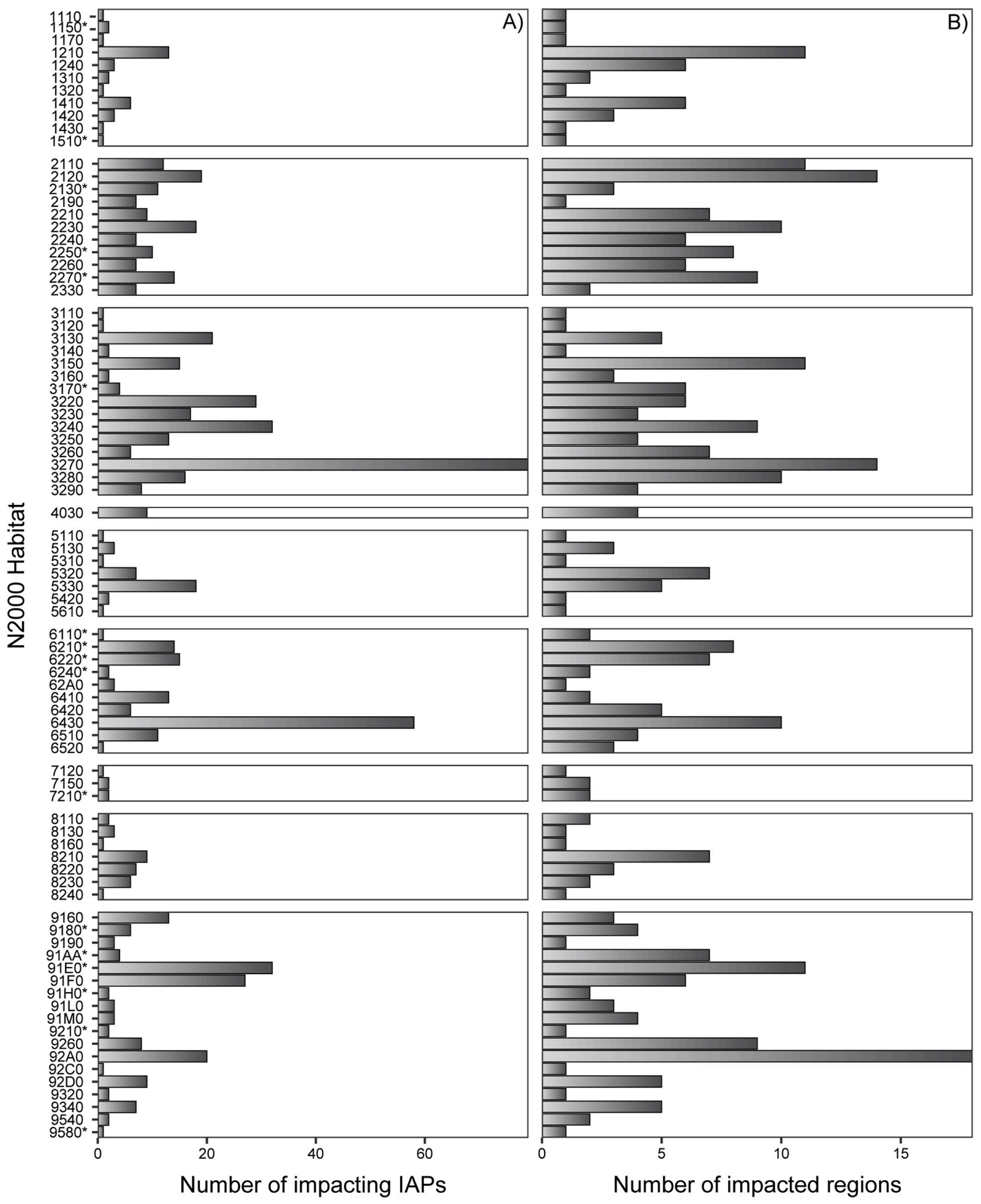

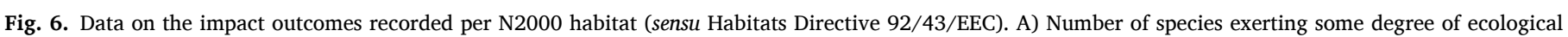
impact for each target N2000 habitat and B) number of administrative regions in which the target N2000 habitat is impacted.

implementation of such a list (see Lazzaro et al., 2019) is currently being carried out by ISPRA, within the Life ASAP project (LIFE15 GIE/IT/001039).

The high number of expert-based assessments in our survey underscores the major difficulty in retrieving suitable and reliable literature on the impacts of IAPs in Italy. Indeed, direct evidence is frequently also lacking for very well-studied species, generally considered a priori to be a serious threat to biodiversity. The gaps in knowledge of the different taxa hinder the study (and management) of the impacts associated with biological invasions, with most papers focusing on a narrow set of already studied species (Hulme et al., 2013; Latombe et al., 2017). This is especially serious because data on impacts are necessary to lay the basis for any generalisation about biological invasions and are mandatory for risk assessment and management (Bolpagni et al., 2014a; Lazzaro et al., 2015).

For example, information concerning A. altissima mainly comes from 
Table 2

Matrices of correlation between the number of N2000 habitats (Habitats), number of macro-categories of N2000 habitats (Macro-habitats) and number of invaded administrative regions (Regions), for each introduction period. In each correlation matrix, the upper triangle (numbers in plain text) displays Spearman's rank correlation coefficient (Spearman's rho), while the lower triangle (numbers in italic) displays its significance.

\begin{tabular}{lllll}
\hline Introduction Period & & Habitats & Macro-habitats & Regions \\
\hline $1492-1799$ & Habitats & - & 0.930 & 0.523 \\
& Macro-habitats & $<0.001$ & - & 0.489 \\
& Regions & 0.003 & 0.007 & - \\
$1800-1950$ & Habitats & - & 0.860 & 0.129 \\
& Macro-habitats & $<0.001$ & - & 0.187 \\
$1951-$ present & Regions & 0.129 & 0.187 & - \\
& Habitats & - & 0.845 & 0.077 \\
& Macro-habitats & $<0.001$ & - & 0.096 \\
& Regions & 0.579 & 0.488 & - \\
\hline
\end{tabular}

Table 3

Analysis of the deviance table for the generalized linear models analysing the effect of life form categories and introduction period on the number of invaded N2000 habitats (Habitats), number of macro-categories of N2000 habitat (Macro-habitats) and number of invaded administrative regions (Regions). $\chi^{2}=$ Likelihood ratio Chi-square; $\mathrm{Df}=$ Degree of freedom; Significance codes: $\mathrm{P}$ value

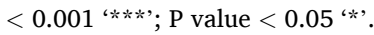

\begin{tabular}{clllll}
\hline Response & Term & $\chi^{2}$ & Df & P value & \\
\hline Habitats & life form & 24.576 & 5 & $<0.001$ & $* * *$ \\
& introduction period & 28.551 & 2 & $<0.001$ & $* * *$ \\
& life form $\times$ introduction & 12.005 & 10 & 0.285 & \\
& period & & & & \\
Macro- & life form & 23.720 & 5 & $<0.001$ & $* * *$ \\
habitats & introduction period & 28.723 & 2 & $<0.001$ & $* * *$ \\
& life form $\times$ introduction & 15.669 & 10 & 0.109 & \\
& period & & & & \\
Regions & life form & 13.725 & 5 & 0.017 & $*$ \\
& introduction period & 52.092 & 2 & $<0.001$ & $* * *$ \\
& life form $\times$ introduction & 15.691 & 10 & 0.109 & \\
& period & & & & \\
\hline
\end{tabular}

regional reports and checklists which often lack direct measurements of the cited impacts (see Badalamenti et al., 2016; Maiorca et al., 2007). Although the impacts caused by this species are relatively well-studied (Castro-Díez et al., 2019), impacts in Italy are only documented for Sardinia (Traveset et al., 2008; Vilà et al., 2006) and the Karst area in northeastern Italy (Uboni et al., 2019) and there is very little literature on impacts outcomes on plant communities or on N2000 habitats. Among the most studied species, Robinia pseudoacacia stands out as a major invasive tree in Europe (Vítková et al., 2017). Many studies in Italy have focused on the impacts of this species (Nascimbene et al., 2012, 2015; Benesperi et al., 2012; Lazzaro et al., 2018; Sitzia et al., 2018; Campagnaro et al., 2018; Gentili et al., 2019). Most authors have found evidence that the rapid expansion of this species in Italy is causing the progressive decline of native forests, with loss of species richness and diversity and a shift in species composition towards nitrophilous assemblages (Benesperi et al., 2012; Lazzaro et al., 2018; Allegrezza et al., 2019). In contrast, other authors have shown that secondary Robinia forests, growing on abandoned lands, may host compositionally heterogeneous plant communities and may contribute to some degree to regional biodiversity (Campagnaro et al., 2018). Nevertheless, as pointed out also by Lazzaro et al. (2018), it is worth mentioning that in many cases Robinia forests replace habitats considered of community interest in Europe (i.e. N2000 habitats 9260, 91B0, 91M0, 91AA*; Montecchiari et al., 2020, and 92A0 among others). Robinia pseudoacacia is also an important forest species, so that one option would be to apply forestry best practice to avoid its escape from areas set aside for cultivation.

Robinia pseudoacacia is also predicted to be one of the most competitive species in a climate change scenario (Kleinbauer et al., 2010), and recently Nascimbene et al. (2020) showed the effects of the interaction between climate change and invasion by $R$. pseudoacacia on the endangered lichen species Lobaria pulmonaria. Biological invasions and climate change (often referred to as "double trouble") are considered two of the key drivers of biodiversity loss, whose interaction will lead to a magnification of the threats to biodiversity worldwide (Mainka and Howard, 2010).

Among the highly invasive tree species, in Northern Italy Prunus serotina and Quercus rubra have also been reported to greatly impact native communities and ecosystem components at the soil level (Gentili et al., 2019; Vegini et al., 2020). Acacia is another genus well-studied in Italy and worldwide. The negative impacts on plant communities of these nitrogen-fixing trees are well documented for several species (e.g., A. dealbata: Lazzaro et al., 2014; Minuto et al., 2020; A. pycnantha: Lazzaro et al., 2015). Likewise, the impacts of $A$. saligna on coastal dune N2000 habitats (Del Vecchio et al., 2013; Bonari et al., 2017; Calabrese et al., 2017).

Carpobrotus acinaciformis, C. edulis and their hybrids (Campoy et al., 2018), is another group of invasive species widely investigated in Italy, whose impacts on both biodiversity (Santoro et al., 2012; Jucker et al., 2013) and soil conditions (Zedda et al., 2010; Santoro et al., 2011; Badalamenti et al., 2016) are well depicted. Their pattern of occurrence at the community level (Carboni et al., 2010; Sperandii et al., 2017) as well as their habitat preference, including N2000 habitats 2120, 2210 and 2250*, have also been studied (Sarmati et al., 2019).

Some specific studies have focused on the impact of different IAPs (e. g. Ambrosia psilostachya, Cenchrus longispinus, Erigeron canadensis, Oenothera stucchii, Senecio inaequidens) on sand dune ecosystems in northeastern Italy, showing significant negative effects on species richness, species diversity and evenness, and plant community composition, with effects increasing from N2000 drift line habitats (1210) to fixeddune habitats (2130) (Del Vecchio et al., 2015).

Unfortunately, once these few well-studied IAPs are excluded, most of the records of impact on plant communities and N2000 habitats collected in the present general assessment derive from expert evaluations. This applies in particular to the species listed among the Invasive Alien plant Species of Union Concern (sensu Regulation (EU) no. 1143/ 2014), both because their spatial distribution in Italy is still scattered or localized (e.g. Alternanthera philoxeroides, Pontederia crassipes) and especially because data on their impacts is still missing (with only a few exceptions; see e.g. Lastrucci et al. (2017) for Myriophyllum aquaticum). The lack of information may also be due to the difficulty in obtaining reliable data for plants and vegetation in aquatic ecosystems, normally extremely time- and money-consuming to sample (Azzella et al., 2017). Indeed, half of the IAPs of Union concern are aquatic or wetland plants (19 out of 36). Despite their high number in the EU list confirming the general poor state of conservation of inland waters (Brundu, 2014; Lastrucci et al., 2017), aquatic IAPs have been so far neglected or little investigated in Italy. However, several studies confirmed their pivotal role in reducing local biodiversity. Bolpagni (2013a, 2013b) and Bolpagni et al. (2017) found that Lagarosiphon major and Elodea nuttallii create extensive submerged meadows that almost completely replace native macrophyte communities belonging to N2000 habitats 3140 and 3150. Nelumbo nucifera and Ludwigia hexapetala seem to actively compete with native species (Bolpagni et al., 2014b; Villa et al., 2017, 2018; Tóth et al., 2019) due to their enhanced competitive ability for limiting resources and their tolerance to edaphic conditions variability (Tóth et al., 2019). Some studies focused on the impact of Lemna minuta on freshwater ecosystems. The results highlighted substantial negative effects on water quality and on aquatic plant and animal communities (Ceschin et al., 2019, 2020), showing that L. minuta causes severe alterations to the local vegetation, often replacing native species, such as the congeneric $L$. minor. Indeed $L$. minuta assimilates available nutrients faster than the native species and shows a higher relative growth rate (Ceschin et al., 2016a, 2016b), characteristics that make this species 

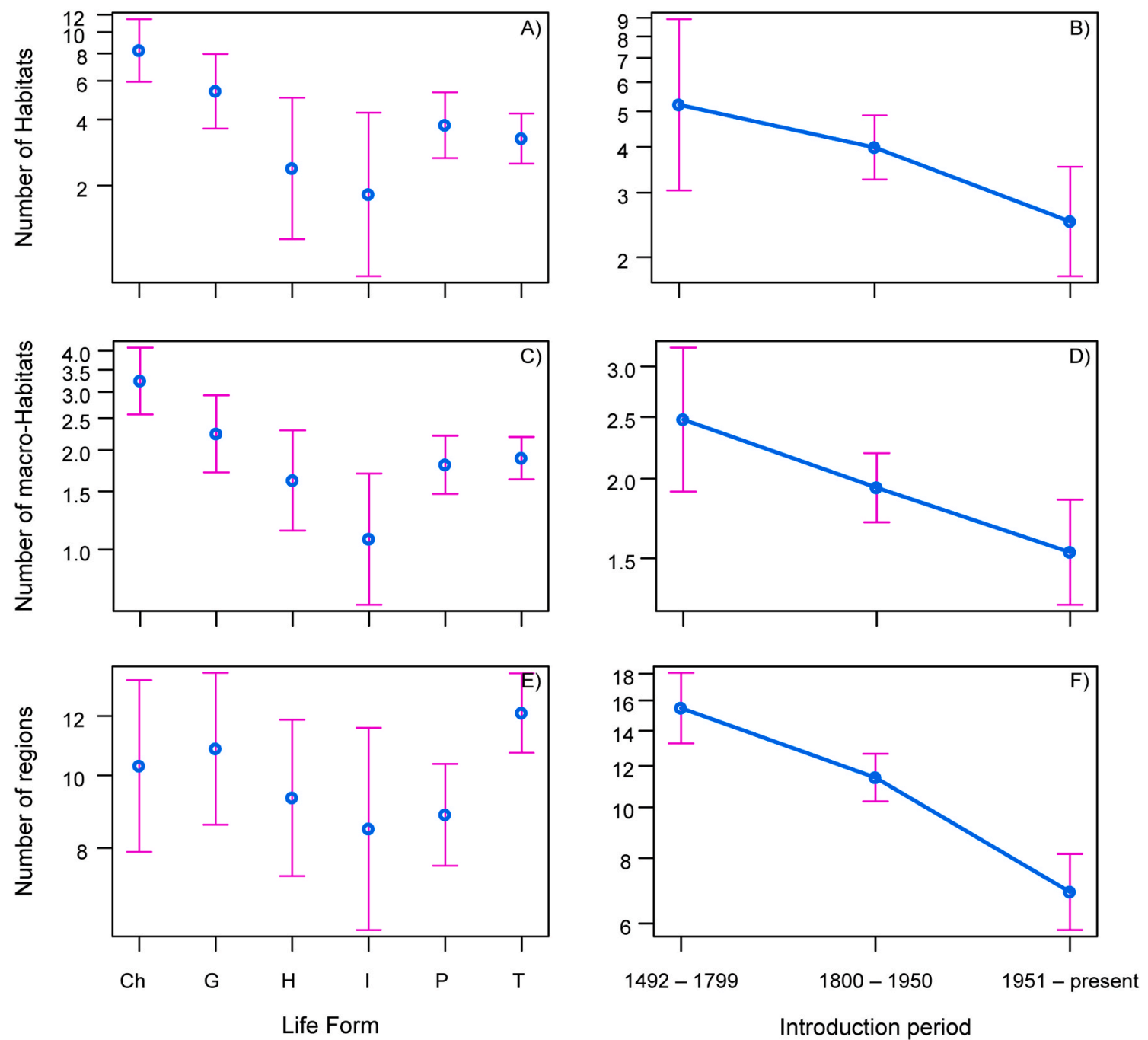

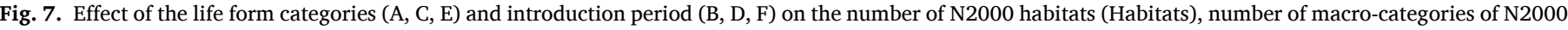

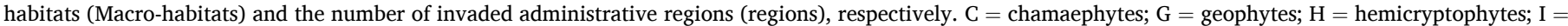
hydrophytes; $\mathrm{P}=$ phanerophytes; $\mathrm{T}=$ terophytes.

highly competitive. However, the scarcity of knowledge on the majority of aquatic IAPs hinders both a correct assessment of the environmental impacts and the planning of actions to be carried out for effective recovery of impacted ecosystems.

Our survey also evidenced a group of well-known and widespread invasive herbs (i.e., Amaranthus retroflexus, Ambrosia artemisiifolia, Artemisia verlotiorum, Bidens frondosa, Erigeron canadensis), that are very competitive in disturbed habitats (agricultural areas, roadsides, ruderal areas) also thanks to their high propagule pressure. Ruderal species are highly opportunistic and it is worth mentioning the presence of Phytolacca americana and Solanum chenopodioides in an old-growth Quercus ilex urban forest disturbed by a severe windstorm in Southern Italy (Bonanomi et al., 2018). Opportunistic alien species, which invest in rapid growth and in sexual reproduction, are a challenging issue in invasion biology since their invasiveness may change during different successional stages (Domènech and Vilà, 2006). For instance, the annual A. artemisiifolia is completely suppressed by late colonists and perennial species after a three-year succession (Gentili et al., 2017). Conversely, the invasion of Solidago canadensis has been reported to modify the trajectory of vegetation succession and to exert a higher negative effect on native diversity in older successional communities (Fenesi et al., 2015a, 2015b).

Finally, this survey showed that the time elapsed since introduction has a highly significant effect on the number of habitats invaded. This highlights the importance of better investigating species of relatively recent introduction, which are not yet truly invasive, but which have considerable potential to invade given the size of the introduced populations. These include some species of Eucalyptus, especially E. camaldulensis, which in recent years has begun to spread in river habitats in Sicily (Badalamenti et al., 2018). In this, as in other cases, biological evolution acts on the introduced species and may enable some alien plants to occupy a broad range of novel habitats until they become invasive (Oduor et al., 2016). Tree species should be carefully monitored because although they take time to become invasive, when they do, the impact is high because of their large biomass.

\section{Conclusions}

Our survey is the first attempt to assess the impact of the most harmful IAPs on plant communities and on N2000 habitats throughout Italy. The study highlighted numerous knowledge gaps which, however, replicate the gaps in plant invasion science ascertained at a global level. The differences in levels of knowledge between the Italian administrative regions is likely linked to dissimilarities in awareness, as shown by regional differences in policies and legislation. Thus, a primary aim of the scientific community should be to even up disparities in knowledge 
at the regional level. Most importantly, we highlighted a glaring lack of evidences, even for well-known invasive species. We also exposed a lack of data on the impacts of IAPs on N2000 habitats, which ought to be a primary focus of conservation efforts. Thus, filling the knowledge gap is a mission of primary importance, to provide data both for risk analysis and to support decision makers. Our results show that Italy needs a coordinated nation-wide strategy to evaluate and manage the risk of invasion in the N2000 network. This need is even more urgent in the light of the compounded effects of biological invasion and climate change, which biodiversity management planning and policy should take into careful consideration.

\section{Funding}

The work of the expert group from Italian Society of Vegetation Science (SISV) was promoted by the Institute for Environmental Protection and Research (ISPRA) and funded by the Ministry of the Environment and Preservation of Land and Sea, within the working program "Programma di lavoro a supporto dell'implementazione del Regolamento UE 1143/2014 sulle specie esotiche invasive" - CIG: ZB71C570F0.

\section{Author contributions}

L.Las., R.Bol., L.Laz., G.Buf. and F.Bra. were involved in designing the methodology and coordinated the work for the data collection on behalf of Italian Society of Vegetation Science. L.Laz., L.Las., R.Bol., G. Buf., R.Gen., M.Lon. and A.Sti. were involved in data analysis and interpretation and drafting the manuscript. All authors provided data for the survey as associated of SISV, critically revised the draft of the manuscript and gave final approval for publication.

\section{CRediT authorship contribution statement}

Lorenzo Lazzaro: Investigation, Writing - review \& editing, Project administration, Visualization, Writing - original draft, Conceptualization, Methodology, Data curation, Formal analysis. Rossano Bolpagni: Investigation, Writing - review \& editing, Project administration, Writing - original draft, Methodology. Gabriella Buffa: Investigation, Writing - review \& editing, Project administration, Writing - original draft, Methodology. Rodolfo Gentili: Investigation, Writing - review \& editing, Writing - original draft. Michele Lonati: Investigation, Writing - review \& editing, Writing - original draft, Formal analysis. Adriano Stinca: Investigation, Writing - review \& editing, Writing - original draft. Alicia Teresa Rosario Acosta: Investigation, Writing - review \& editing. Michele Adorni: Investigation, Writing - review \& editing. Michele Aleffi: Investigation, Writing - review \& editing. Marina Allegrezza: Investigation, Writing - review \& editing. Claudia Angiolini: Investigation, Writing - review \& editing. Silvia Assini: Investigation, Writing - review \& editing. Simonetta Bagella: Investigation, Writing - review \& editing. Gianmaria Bonari: Investigation, Writing review \& editing. Maurizio Bovio: Investigation, Writing - review \& editing. Francesco Bracco: Investigation, Writing - review \& editing, Project administration, Methodology. Giuseppe Brundu: Investigation, Writing - review \& editing. Marco Caccianiga: Investigation, Writing review \& editing. Lucilla Carnevali: Writing - review \& editing, Funding acquisition. Valter Di Cecco: Investigation, Writing - review \& editing. Simona Ceschin: Investigation, Writing - review \& editing. Giampiero Ciaschetti: Investigation, Writing - review \& editing. Annalena Cogoni: Investigation, Writing - review \& editing. Bruno Foggi: Investigation, Writing - review \& editing. Anna Rita Frattaroli: Investigation, Writing - review \& editing. Piero Genovesi: Writing review \& editing, Funding acquisition. Daniela Gigante: Investigation, Writing - review \& editing. Fernando Lucchese: Investigation, Writing review \& editing. Andrea Mainetti: Investigation, Writing - review \& editing. Mauro Mariotti: Investigation, Writing - review \& editing.
Pietro Minissale: Investigation, Writing - review \& editing. Bruno Paura: Investigation, Writing - review \& editing. Mauro Pellizzari: Investigation, Writing - review \& editing. Enrico Vito Perrino: Investigation, Writing - review \& editing. Gianfranco Pirone: Investigation, Writing - review \& editing. Laura Poggio: Investigation, Writing - review \& editing. Livio Poldini: Investigation, Writing - review \& editing. Silvia Poponessi: Investigation, Writing - review \& editing. Irene Prisco: Investigation, Writing - review \& editing. Filippo Prosser: Investigation, Writing - review \& editing. Marta Puglisi: Investigation, Writing - review \& editing. Leonardo Rosati: Investigation, Writing review \& editing. Alberto Selvaggi: Investigation, Writing - review \& editing. Lucio Sottovia: Investigation, Writing - review \& editing. Giovanni Spampinato: Investigation, Writing - review \& editing. Angela Stanisci: Investigation, Writing - review \& editing. Roberto Venanzoni: Investigation, Writing - review \& editing, Funding acquisition. Daniele Viciani: Investigation, Writing - review \& editing. Marisa Vidali: Investigation, Writing - review \& editing. Mariacristina Villani: Investigation, Writing - review \& editing. Lorenzo Lastrucci: Investigation, Writing - review \& editing, Project administration, Methodology.

\section{Declaration of competing interest}

The authors declare that they have no known competing financial interests or personal relationships that could have appeared to influence the work reported in this paper.

\section{Appendix A. Supplementary data}

Supplementary data to this article can be found online at https://doi. org/10.1016/j.jenvman.2020.111140.

\section{References}

Allegrezza, M., Montecchiari, S., Ottaviani, C., Pelliccia, V., Tesei, G., 2019. Syntaxonomy of the Robinia pseudoacacia communities in the central peri-adriatic sector of the Italian peninsula. Plant Biosystems - An International Journal Dealing with all Aspects of Plant Biology 153, 616-623. https://doi.org/10.1080/ 11263504.2019.1610108.

Aronson, M.F.J., Patel, M.V., O'Neill, K.M., Ehrenfeld, J.G., 2017. Urban riparian systems function as corridors for both native and invasive plant species. Biol. Invasions 19, 3645-3657. https://doi.org/10.1007/s10530-017-1583-1.

Azzella, M.M., Bresciani, M., Nizzoli, D., Bolpagni, R., 2017. Aquatic vegetation in deep lakes: macrophyte co-occurrence patterns and environmental determinants. J. Limnol. 76 (s1), 97-108. https://doi.org/10.4081/jlimnol.2017.1687.

Bacher, S., Blackburn, T.M., Essl, F., Genovesi, P., Heikkilä, J., Jeschke, J.M., Jones, G., Keller, R., Kenis, M., Kueffer, C., Martinou, A.F., Nentwig, W., Pergl, J., Pyšek, P., Rabitsch, W., Richardson, D.M., Roy, H.E., Saul, W.-C., Scalera, R., Vilà, M., Wilson, J.R.U., Kumschick, S., 2017. Socio-economic impact classification of alien taxa (SEICAT). Methods in Ecology and Evolution 9, 159-168. https://doi.org/ 10.1111/2041-210x.12844.

Badalamenti, E., Cusimano, D., La Mantia, T., Pasta, S., Romano, S., Troia, A., Ilardi, V., 2018. The ongoing naturalisation of Eucalyptus spp. in the Mediterranean Basin: new threats to native species and habitats. Aust. For. 81, 239-249. https://doi.org/ 10.1080/00049158.2018.1533512.

Badalamenti, E., Gristina, L., Laudicina, V.A., Novara, A., Pasta, S., La Mantia, T., 2016. The impact of Carpobrotus cfr. acinaciformis (L.) L. Bolus on soil nutrients microbial communities structure and native plant communities in Mediterranean ecosystems. Plant Soil 409, 19-34. https://doi.org/10.1007/s11104-016-2924-z.

Benesperi, R., Giuliani, C., Zanetti, S., Gennai, M., Lippi, M.M., Guidi, T., Nascimbene, J., Foggi, B., 2012. Forest plant diversity is threatened by Robinia pseudoacacia (blacklocust) invasion. Biodivers. Conserv. 21, 3555-3568. https://doi.org/10.1007/ s10531-012-0380-5.

Biondi, E., Blasi, C., Burrascano, S., Casavecchia, S., Copiz, R., Vico, E.D., Galdenzi, D., Gigante, D., Lasen, C., Spampinato, G., Venanzoni, R., Zivkovic, L., 2009. Italian interpretation manual of the 92/43/EEC directive habitats. Accessed March 24, 2020. URL: http://vnr.unipg.it/habitat/.

Blackburn, T.M., Essl, F., Evans, T., Hulme, P.E., Jeschke, J.M., Kühn, I., Kumschick, S., Marková, Z., Mrugała, A., Nentwig, W., Pergl, J., Pyšek, P., Rabitsch, W., Ricciardi, A., Richardson, D.M., Sendek, A., Vilà, M., Wilson, J.R.U., Winter, M., Genovesi, P., Bacher, S., 2014. A unified classification of alien species based on the magnitude of their environmental impacts. PLoS Biol. 12, e1001850 https://doi.org/ 10.1371/journal.pbio.1001850.

Bolpagni, R., 2013a. Multimetric indices based on vegetation data for assessing ecological and hydromorphological quality of a man-regulated lake. Ann. Bot. (Rome) 3, 87-95. https://doi.org/10.4462/annbotrm-10236. 
Bolpagni, R., 2013b. Macrophyte richness and aquatic vegetation complexity of the lake Idro (Northern Italy). Ann. Bot. (Rome) 3, 35-43. https://doi.org/10.4462/ annbotrm-10207.

Bolpagni, R., Azzella, M.M., Agostinelli, C., Beghi, A., Bettoni, E., Brusa, G., De Molli, C., Formenti, R., Galimberti, F., Cerabolini, B.E.L., 2017. Integrating the water framework directive into the habitats directive: analysis of distribution patterns of lacustrine EU habitats in lakes of Lombardy (Northern Italy). J. Limnol. 76, 75-83. https://doi.org/10.4081/jlimnol.2017.1627.

Bolpagni, R., Bartoli, M., Viaroli, P., 2013. Species and functional plant diversity in a heavily impacted riverscape: implications for threatened hydro-hygrophilous flora conservation. Limnologica 43, 230-238. https://doi.org/10.1016/j. limno.2012.11.001.

Bolpagni, R., Bresciani, M., Laini, A., Pinardi, M., Matta, E., Ampe, E.M., Giardino, C., Viaroli, P., Bartoli, M., 2014b. Remote sensing of phytoplankton-macrophyte coexistence in shallow hypereutrophic fluvial lakes. Hydrobiologia 737, 67-76. https://doi.org/10.1007/s10750-013-1800-6.

Bolpagni, R., Laini, A., Soana, E., Tomaselli, M., Nascimbene, J., 2014a. Growth performance of Vallisneria spiralis under oligotrophic conditions supports its potential invasiveness in mid-elevation freshwaters. Weed Res. 55, 185-194. https://doi.org/10.1111/wre.12128.

Bolpagni, R., Piotti, A., 2015. The importance of being natural in a human-altered riverscape: role of wetland type in supporting habitat heterogeneity and the functional diversity of vegetation. Aquat. Conserv. Mar. Freshw. Ecosyst. 26, 1168-1183. https://doi.org/10.1002/aqc.2604.

Bonanomi, G., Incerti, G., El-Gawad, A.M.A., Sarker, T.C., Stinca, A., Motti, R., Cesarano, G., Teobaldelli, M., Saulino, L., Cona, F., Chirico, G.B., Mazzoleni, S., Saracino, A., 2018. Windstorm disturbance triggers multiple species invasion in an urban Mediterranean forest. iFor. Biogeosci. For. 11, 64-71. https://doi.org/ 10.3832/ifor2374-010.

Bonari, G., Acosta, A.T.R., Angiolini, C., 2017. Mediterranean coastal pine forest stands: understorey distinctiveness or not? For. Ecol. Manag. 391, 19-28. https://doi.org/ 10.1016/j.foreco.2017.02.002.

Brundu, G., 2014. Plant invaders in European and Mediterranean inland waters: profiles distribution, and threats. Hydrobiologia 746, 61-79. https://doi.org/10.1007/ s10750-014-1910-9.

Brundu, G., Minicante, S.A., Barni, E., Bolpagni, R., Caddeo, A., Celesti-Grapow, L., Cogoni, A., Galasso, G., Iiriti, G., Lazzaro, L., Loi, M.C., Lozano, V., Marignani, M., Montagnani, C., Siniscalco, C., 2020. Managing plant invasions using legislation tools: an analysis of the national and regional regulations for non-native plants in Italy. Ann. Bot. (Rome) 1-12. https://doi.org/10.13133/2239-3129/16508.

Buffa, G., Del Vecchio, S., Fantinato, E., Milano, V., 2018. Local versus landscape-scale effects of anthropogenic land-use on forest species richness. Acta Oecol. 86, 49-56.

Calabrese, V., Frate, L., Iannotta, F., Prisco, I., Stanisci, A., 2017. Acacia saligna: an invasive species on the coast of Molise (southern Italy). Forest@ - Rivista di Selvicoltura ed Ecologia Forestale 14, 28-33. https://doi.org/10.3832/efor2211013.

Campagnaro, T., Nascimbene, J., Tasinazzo, S., Trentanovi, G., Sitzia, T., 2018. Exploring patterns drivers and structure of plant community composition in alien Robinia pseudoacacia secondary woodlands. iFor. Biogeosci. For. 11, 586-593. https://doi. org/10.3832/ifor2687-011.

Campoy, J.G., Acosta, A.T.R., Affre, L., Barreiro, R., Brundu, G., Buisson, E., González, L., Lema, M., Novoa, A., Retuerto, R., Roiloa, S.R., Fagúndez, J., 2018. Monographs of invasive plants in Europe: Carpobrotus. Botany Letters 165, 440-475. https://doi. org $/ 10.1080 / 23818107.2018 .1487884$.

Carboni, M., Santoro, R., Acosta, A.T.R., 2010. Are some communities of the coastal dune zonation more susceptible to alien plant invasion? J. Plant Ecol. 3, 139-147. https:// doi.org/10.1093/jpe/rtp037.

Castro-Díez, P., Vaz, A.S., Silva, J.S., Loo, M., Alonso, Álvaro, Aponte, C., Bayón, Álvaro, Bellingham, P.J., Chiuffo, M.C., DiManno, N., Julian, K., Kandert, S., Porta, N.L., Marchante, H., Maule, H.G., Mayfield, M.M., Metcalfe, D., Monteverdi, M.C., Núñez, M.A., Ostertag, R., Parker, I.M., Peltzer, D.A., Potgieter, L.J., Raymundo, M., Rayome, D., Reisman-Berman, O., Richardson, D.M., Roos, R.E., Saldaña, A. Shackleton, R.T., Torres, A., Trudgen, M., Urban, J., Vicente, J.R., Vilà, M., Ylioja, T., Zenni, R.D., Godoy, O., 2019. Global effects of non-native tree species on multiple ecosystem services. Biol. Rev. https://doi.org/10.1111/brv.12511.

Celesti-Grapow, L., Alessandrini, A., Arrigoni, P.V., Banfi, E., Bernardo, L., Bovio, M., Brundu, G., Cagiotti, M.R., Camarda, I., Carli, E., Conti, F., Fascetti, S., Galasso, G., Gubellini, L., La Valva, V., Lucchese, F., Marchiori, S., Mazzola, P., Peccenini, S., Poldini, L., Pretto, F., Prosser, F., Siniscalco, C., Villani, M.C., Viegi, L., Wilhalm, T., Blasi, C., 2009. Inventory of the non-native flora of Italy. Plant Biosystems - An International Journal Dealing with all Aspects of Plant Biology 143, 386-430. https://doi.org/10.1080/11263500902722824.

Celesti-Grapow, L., Bassi, L., Brundu, G., Camarda, I., Carli, E., D’Auria, G., Guacchio, E. D., Domina, G., Ferretti, G., Foggi, B., Lazzaro, L., Mazzola, P., Peccenini, S., Pretto, F., Stinca, A., Blasi, C., 2016. Plant invasions on small Mediterranean islands: an overview. Plant Biosystems - An International Journal Dealing with all Aspects of Plant Biology 150, 1119-1133. https://doi.org/10.1080/11263504.2016.1218974.

Ceschin, S., Abati, S., Leacche, I., Iamonico, D., Iberite, M., Zuccarello, V., 2016a. Does the alien Lemna minuta show an invasive behavior outside its original range? Evidence of antagonism with the native $L$. minor in central Italy. Int. Rev. Hydrobiol. 101, 173-181. https://doi.org/10.1002/iroh.201601841.

Ceschin, S., Abati, S., Traversetti, L., Spani, F., Del Grosso, F., Scalici, M., 2019. Effects of the invasive duckweed Lemna minuta on aquatic animals: evidence from an indoor experiment. Plant Biosystems - An International Journal Dealing with all Aspects of Plant Biology 153, 749-755. https://doi.org/10.1080/11263504.2018.1549605.
Ceschin, S., Della Bella, V., Piccari, F., Abati, S., 2016b. Colonization dynamics of the alien macrophyte Lemna minuta Kunth: a case study from a semi-natural pond in Appia Antica Regional Park (Rome Italy). Fundamental and Applied Limnology/ Arch. Hydrobiol. 188, 93-101. https://doi.org/10.1127/fal/2016/0870.

Ceschin, S., Ferrante, G., Mariani, F., Traversetti, L., Ellwood, N.T.W., 2020. Habitat change and alteration of plant and invertebrate communities in waterbodies dominated by the invasive alien macrophyte Lemna minuta Kunth. Biol. Invasions 22, 1325-1337. https://doi.org/10.1007/s10530-019-02185-5.

Del Vecchio, S., Acosta, A.T.R., Stanisci, A., 2013. The impact of Acacia saligna invasion on Italian coastal dune EC habitats. Comptes Rendus Biol. 336, 364-369. https://doi. org/10.1016/j.crvi.2013.06.004.

Del Vecchio, S., Pizzo, L., Buffa, G., 2015. The response of plant community diversity to alien invasion: evidence from a sand dune time series. Biodivers. Conserv. 24, 371-392. https://doi.org/10.1007/s10531-014-0814-3.

Domènech, R., Vilà, M., 2006. The role of successional stage vegetation type and soil disturbance in the invasion of the alien grass Cortaderia selloana. J. Veg. Sci. 17, 591-598. https://doi.org/10.1111/j.1654-1103.2006.tb02483.x.

European Commission, 2013. Interpretation manual of European Union habitats EUR 28. Environment DG. Accessed March 24, 2020. URL: http://ec.europa.eu/enviro nment/nature/legislation/habitatsdirective/docs/Int_Manual_EU28.pdf.

Fenesi, A., Geréd, J., Meiners, S.J., Tóthmérész, B., Török, P., Ruprecht, E., 2015a. Does disturbance enhance the competitive effect of the invasive Solidago canadensis on the performance of two native grasses? Biol. Invasions 17, 3303-3315. https://doi.org/ 10.1007/s10530-015-0954-8.

Fenesi, A., Vágási, C.I., Beldean, M., Földesi, R., Kolcsár, L.-P., Shapiro, J.T., Török, E., Kovács-Hostyánszki, A., 2015b. Solidago canadensis impacts on native plant and pollinator communities in different-aged old fields. Basic Appl. Ecol. 16, 335-346. https://doi.org/10.1016/j.baae.2015.03.003.

Friedrichs, M., Hermoso, V., Bremerich, V., Langhans, S.D., 2018. Evaluation of habitat protection under the European Natura 2000 conservation network. The example for Germany. PloS One 13, e0208264. https://doi.org/10.1371/journal.pone.0208264.

Galasso, G., Conti, F., Peruzzi, L., Ardenghi, N.M.G., Banfi, E., Celesti-Grapow, L., Albano, A., Alessandrini, A., Bacchetta, G., Ballelli, S., Mazzanti, M.B., Barberis, G., Bernardo, L., Blasi, C., Bouvet, D., Bovio, M., Cecchi, L., Guacchio, E.D., Domina, G., Fascetti, S., Gallo, L., Gubellini, L., Guiggi, A., Iamonico, D., Iberite, M., JiménezMejías, P., Lattanzi, E., Marchetti, D., Martinetto, E., Masin, R.R., Medagli, P., Passalacqua, N.G., Peccenini, S., Pennesi, R., Pierini, B., Podda, L., Poldini, L., Prosser, F., Raimondo, F.M., Roma-Marzio, F., Rosati, L., Santangelo, A., Scoppola, A., Scortegagna, S., Selvaggi, A., Selvi, F., Soldano, A., Stinca, A., Wagensommer, R.P., Wilhalm, T., Bartolucci, F., 2018a. An updated checklist of the vascular flora alien to Italy. Plant Biosystems - An International Journal Dealing with all Aspects of Plant Biology 152, 556-592. https://doi.org/10.1080/ 11263504.2018.1441197.

Galasso, G., Domina, G., Adorni, M., Ardenghi, N.M.G., Bonari, G., Buono, S., Cancellieri, L., Chianese, G., Ferretti, G., Fiaschi, T., Forte, L., Guarino, R., Labadessa, R., Lastrucci, L., Lazzaro, L., Magrini, S., Minuto, L., Mossini, S., Olivieri, N., Scoppola, A., Stinca, A., Turcato, C., Nepi, C., 2018b. Notulae to the Italian alien vascular flora: 5. Ital. Bot. 5, 45-56. https://doi.org/10.3897/ italianbotanist.5.25910.

Galasso, G., Domina, G., Alessandrini, A., Ardenghi, N.M.G., Bacchetta, G., Ballelli, S., Bartolucci, F., Brundu, G., Buono, S., Busnardo, G., Calvia, G., Capece, P., D’Antraccoli, M., Nuzzo, L.D., Fanfarillo, E., Ferretti, G., Guarino, R., Iamonico, D., Iberite, M., Latini, M., Lazzaro, L., Lonati, M., Lozano, V., Magrini, S., Mei, G., Mereu, G., Moro, A., Mugnai, M., Nicolella, G., Nimis, P.L., Olivieri, N., Pennesi, R., Peruzzi, L., Podda, L., Probo, M., Prosser, F., Enri, S.R., Roma-Marzio, F., Ruggero, A., Scafidi, F., Stinca, A., Nepi, C., 2018c. Notulae to the Italian alien vascular flora: 6. Ital. Bot. 6, 65-90. https://doi.org/10.3897/ italianbotanist.6.30560.

Gallardo, B., Aldridge, D.C., González-Moreno, P., Pergl, J., Pizarro, M., Pyšek, P., Thuiller, W., Yesson, C., Vilà, M., 2017. Protected areas offer refuge from invasive species spreading under climate change. Global Change Biol. 23, 5331-5343. https://doi.org/10.1111/gcb.13798.

Gentili, R., Ferrè, C., Cardarelli, E., Montagnani, C., Bogliani, G., Citterio, S., Comolli, R., 2019. Comparing negative impacts of Prunus serotina, Quercus rubra and Robinia pseudoacacia on native forest ecosystems. Forests 10, 842. https://doi.org/10.3390/ f10100842.

Gentili, R., Montagnani, C., Gilardelli, F., Guarino, M.F., Citterio, S., 2017. Let native species take their course: Ambrosia artemisiifolia replacement during natural or artificial succession. Acta Oecol. 82, 32-40. https://doi.org/10.1016/j. actao.2017.05.007.

Gigante, D., Acosta, A.T.R., Agrillo, E., Armiraglio, S., Assini, S., Attorre, F., Bagella, S., Buffa, G., Casella, L., Giancola, C., Giusso del Galdo, G.P., Marcenò, C., Pezzi, G., Prisco, I., Venanzoni, R., Viciani, D., 2018. Habitat conservation in Italy: the state of the art in the light of the first European red list of terrestrial and freshwater habitats. Rendiconti lincei. Scienze Fisiche e Naturali 29, 251-265.

GISD, 2020. Global invasive species database. Accessed March 24, 2020. URL: http://www.iucngisd.org/gisd/.

Guerra, C., Baquero, R.A., Gutiérrez-Arellano, D., Nicola, G.G., 2018. Is the Natura 2000 network effective to prevent the biological invasions? Global Ecology and Conservation 16, e00497. https://doi.org/10.1016/j.gecco.2018.e00497.

Hulme, P.E., Pyšek, P., Jarošík, V., Pergl, J., Schaffner, U., Vilà, M., 2013. Bias and error in understanding plant invasion impacts. Trends Ecol. Evol. 28, 212-218. https:// doi.org/10.1016/j.tree.2012.10.010.

Jucker, T., Carboni, M., Acosta, A.T.R., 2013. Going beyond taxonomic diversity: deconstructing biodiversity patterns reveals the true cost of iceplant invasion. Divers. Distrib. 19, 1566-1577. https://doi.org/10.1111/ddi.12124. 
Kleinbauer, I., Dullinger, S., Peterseil, J., Essl, F., 2010. Climate change might drive the invasive tree Robinia pseudacacia into nature reserves and endangered habitats. Biol. Conserv. 143, 382-390. https://doi.org/10.1016/j.biocon.2009.10.024.

Lastrucci, L., Lazzaro, L., Dell’Olmo, L., Foggi, B., Cianferoni, F., 2017. Impacts of Myriophyllum aquaticum invasion in a Mediterranean wetland on plant and macroarthropod communities. Plant Biosystems - An International Journal Dealing with all Aspects of Plant Biology 152, 427-435. https://doi.org/10.1080/ 11263504.2017.1303002.

Latombe, G., Pyšek, P., Jeschke, J.M., Blackburn, T.M., Bacher, S., Capinha, C., Costello, M.J., Fernández, M., Gregory, R.D., Hobern, D., Hui, C., Jetz, W., Kumschick, S., McGrannachan, C., Pergl, J., Roy, H.E., Scalera, R., Squires, Z.E., Wilson, J.R.U., Winter, M., Genovesi, P., McGeoch, M.A., 2017. A vision for global monitoring of biological invasions. Biol. Conserv. 213, 295-308. https://doi.org/ 10.1016/j.biocon.2016.06.013.

Lazzaro, L., Bolpagni, R., Barni, E., Brundu, G., Blasi, C., Siniscalco, C., CelestiGrapow, L., 2019. Towards alien plant prioritization in Italy: methodological issues and first results. Plant Biosystems - An International Journal Dealing with all Aspects of Plant Biology 153, 740-746. https://doi.org/10.1080/11263504.2019.1640310.

Lazzaro, L., Giuliani, C., Benesperi, R., Calamassi, R., Foggi, B., 2015. Plant species loss and community nestedness after leguminous tree Acacia pycnantha invasion in a Mediterranean ecosystem. Folia Geobot. 50, 229-238. https://doi.org/10.1007/ s12224-015-9222-Z.

Lazzaro, L., Giuliani, C., Fabiani, A., Agnelli, A.E., Pastorelli, R., Lagomarsino, A., Benesperi, R., Calamassi, R., Foggi, B., 2014. Soil and plant changing after invasion: the case of Acacia dealbata in a Mediterranean ecosystem. Sci. Total Environ. 497-498, 491-498. https://doi.org/10.1016/j.scitotenv.2014.08.014.

Lazzaro, L., Mazza, G., dErrico, G., Fabiani, A., Giuliani, C., Inghilesi, A.F., Lagomarsino, A., Landi, S., Lastrucci, L., Pastorelli, R., Roversi, P.F., Torrini, G., Tricarico, E., Foggi, B., 2018. How ecosystems change following invasion by Robinia pseudoacacia: insights from soil chemical properties and soil microbial nematode, microarthropod and plant communities. Sci. Total Environ. 622-623, 1509-1518. https://doi.org/10.1016/j.scitotenv.2017.10.017.

Mainka, S.A., Howard, G.W., 2010. Climate change and invasive species: double jeopardy. Integr. Zool. 5, 102-111. https://doi.org/10.1111/j.17494877.2010.00193.x.

Maes, J., 2013. A Model for the Assessment of Habitat Conservation Status in the EU. JRC Scientific and Policy Report. European Commission Joint Research Centre Institute for Environment and Sustainability. Publication Office of the European Commission, Luxembourg.

Maiorca, G., Spampinato, G., Crisafulli, A., Cameriere, P., 2007. Flora vascolare e vegetazione della Riserva Naturale Regionale Foce del Fiume Crati (Calabria Italia meridionale). Webbia 62, 121-174. https://doi.org/10.1080/ 00837792.2007.10670821.

Malavasi, M., Acosta, A.T.R., Carranza, M.L., Bartolozzi, L., Basset, A., Bassignana, M., Campanaro, A., Canullo, R., Carruggio, F., Cavallaro, V., Cianferoni, F., Cindolo, C., Cocciuffa, C., Corriero, G., DAmico, F.S., Forte, L., Freppaz, M., Mantino, F., Matteucci, G., Pierri, C., Stanisci, A., Colangelo, P., 2018. Plant invasions in Italy: an integrative approach using the European LifeWatch infrastructure database. Ecol. Indicat. 91, 182-188. https://doi.org/10.1016/j.ecolind.2018.03.038.

Mazaris, A.D., Katsanevakis, S., 2018. The threat of biological invasions is underrepresented in the marine protected areas of the European Natura 2000 network. Biol. Conserv. 225, 208-212. https://doi.org/10.1016/j.biocon.2018.07.007.

McLean, P., Gallien, L., Wilson, J.R.U., Gaertner, M., Richardson, D.M., 2017. Small urban centres as launching sites for plant invasions in natural areas: insights from South Africa. Biol. Invasions 19, 3541-3555. https://doi.org/10.1007/s10530-0171600-4.

Minuto, L., Casazza, G., Dagnino, D., Guerrina, M., Macrì, C., Zappa, E., Mariotti, M.G., 2020. Reproductive traits of the invasive species Acacia dealbata in the Northern Mediterranean basin. Ann. Bot. (Rome) 10, 13-20. https://doi.org/10.13133/22393129/15642.

Montecchiari, S., Tesei, G., Allegrezza, M., 2020. Effects of Robinia pseudoacacia coverage on diversity and environmental conditions of central-northern Italian Quercus pubescens sub-Mediterranean forests (Habitat code 91AA*): a threshold assessment. Ann. Bot. (Rome) 10, 33-54. https://doi.org/10.13133/2239-3129/16447.

Nascimbene, J., Benesperi, R., Casazza, G., Chiarucci, A., Giordani, P., 2020. Range shifts of native and invasive trees exacerbate the impact of climate change on epiphyte distribution: the case of lung lichen and black locust in Italy. Sci. Total Environ. 735, 139537.

Nascimbene, J., Lazzaro, L., Benesperi, R., 2015. Patterns of $\beta$-diversity and similarity reveal biotic homogenization of epiphytic lichen communities associated with the spread of black locust forests. Fungal Ecology 14, 1-7. https://doi.org/10.1016/j. funeco. 2014.10.006.

Nascimbene, J., Nimis, P.L., Benesperi, R., 2012. Mature non-native black-locust (Robinia pseudoacacia L.) forest does not regain the lichen diversity of the natural forest. Sci. Total Environ. 421-422, 197-202. https://doi.org/10.1016/j. scitotenv.2012.01.051.

Oduor, A.M.O., Leimu, R., van Kleunen, M., 2016. Invasive plant species are locally adapted just as frequently and at least as strongly as native plant species. J. Ecol. 104, 957-968. https://doi.org/10.1111/1365-2745.12578.

Pyšek, P., Jarošík, V., Hulme, P.E., Pergl, J., Hejda, M., Schaffner, U., Vilà, M., 2012. A global assessment of invasive plant impacts on resident species, communities and ecosystems: the interaction of impact measures, invading species' traits and environment. Global Change Biol. 18 (5), 1725-1737.

R Core Team, 2019. R: A Language and Environment for Statistical Computing. R Foundation for Statistical Computing, Vienna, Austria. URL. https://www.r-project. org/.
Santoro, R., Carboni, M., Carranza, M.L., Acosta, A.T.R., 2012. Focal species diversity patterns can provide diagnostic information on plant invasions. J. Nat. Conserv. 20, 85-91. https://doi.org/10.1016/j.jnc.2011.08.003.

Santoro, R., Jucker, T., Carranza, M., Acosta, A.T.R., 2011. Assessing the effects of Carpobrotus invasion on coastal dune soils. Does the nature of the invaded habitat matter? Community Ecol. 12, 234-240. https://doi.org/10.1556/ comec.12.2011.2.12.

Sarmati, S., Conti, L., Acosta, A.T.R., 2019. Carpobrotus acinaciformis vs Carpobrotus edulis: are there any differences in their impact on coastal dune plant biodiversity? Flora 257, 151422. https://doi.org/10.1016/j.flora.2019.151422.

Seebens, H., Blackburn, T.M., Dyer, E.E., Genovesi, P., Hulme, P.E., Jeschke, J.M., Pagad, S., Pyšek, P., Winter, M., Arianoutsou, M., Bacher, S., Blasius, B., Brundu, G., Capinha, C., Celesti-Grapow, L., Dawson, W., Dullinger, S., Fuentes, N., Jäger, H., Kartesz, J., Kenis, M., Kreft, H., Kühn, I., Lenzner, B., Liebhold, A., Mosena, A., Moser, D., Nishino, M., Pearman, D., Pergl, J., Rabitsch, W., Rojas-Sandoval, J., Roques, A., Rorke, S., Rossinelli, S., Roy, H.E., Scalera, R., Schindler, S., Štajerová, K., Tokarska-Guzik, B., van Kleunen, M., Walker, K., Weigelt, P., Yamanaka, T., Essl, F., 2017. No saturation in the accumulation of alien species worldwide. Nat. Commun. 8, 14435. https://doi.org/10.1038/ncomms14435.

Sitzia, T., Campagnaro, T., Kotze, D.J., Nardi, S., Ertani, A., 2018. The invasion of abandoned fields by a major alien tree filters understory plant traits in novel forest ecosystems. Sci. Rep. 8, 8410. https://doi.org/10.1038/s41598-018-26493-3.

Sperandii, M.G., Prisco, I., Acosta, A.T.R., 2017. Hard times for Italian coastal dunes: insights from a diachronic analysis based on random plots. Biodivers. Conserv. 27, 633-646. https://doi.org/10.1007/s10531-017-1454-1.

Traveset, A., Brundu, G., Carta, L., Mprezetou, I., Lambdon, P., Manca, M., Médail, F., Moragues, E., Rodríguez-Pérez, J., Siamantziouras, A.-S.D., Suehs, C.M., Troumbis, A.Y., Vilà, M., Hulme, P.E., 2008. Consistent performance of invasive plant species within and among islands of the Mediterranean basin. Biol. Invasions 10, 847-858. https://doi.org/10.1007/s10530-008-9245-y.

Trochet, A., Schmeller, D., 2013. Effectiveness of the Natura 2000 network to cover threatened species. Nat. Conserv. 4, 35-53. https://doi.org/10.3897/ natureconservation.4.3626.

Tóth, V.R., Villa, P., Pinardi, M., Bresciani, M., 2019. Aspects of invasiveness of Ludwigia and Nelumbo in shallow temperate fluvial lakes. Front. Plant Sci. 10 https://doi.org/ 10.3389/fpls.2019.00647.

Uboni, C., Tordoni, E., Brandmayr, P., Battistella, S., Bragato, G., Castello, M., Colombetta, G., Poldini, L., Bacaro, G., 2019. Exploring cross-taxon congruence between carabid beetles (Coleoptera: carabidae) and vascular plants in sites invaded by Ailanthus altissima versus non-invaded sites: the explicative power of biotic and abiotic factors. Ecol. Indicat. 103, 145-155. https://doi.org/10.1016/j. ecolind.2019.03.052.

Vanderhoeven, S., Branquart, E., Casaer, J., D'hondt, B., Hulme, P.E., Shwartz, A., Strubbe, D., Turbé, A., Verreycken, H., Adriaens, T., 2017. Beyond protocols: improving the reliability of expert-based risk analysis underpinning invasive species policies. Biol. Invasions 19, 2507-2517. https://doi.org/10.1007/s10530-017-1434$0,2017$.

Vegini, E., Lastrucci, L., Lazzaro, L., Cardarelli, E., Martignoni, M., 2020. Impact of Prunus serotina Ehrh. invasion on heathland vegetation: a case of study in NorthWestern Italy. Biologia 75, 327-336. https://doi.org/10.2478/s11756-019-00408-7.

Viciani, D. Vidali, M., Gigante, D., Bolpagni, R., Villani, M., Acosta, A.T. R., Adorni, M., Aleffi, M., Allegrezza, M., Angiolini, C., Assini, S., Bagella, S., Bonari, G., Bovio, M., Bracco, F., Brundu, G., Buffa, G., Caccianiga, M., Carnevali, L., Ceschin, S., Ciaschetti, G., Cogoni, A., Di Cecco, V.D., Foggi, B., Frattaroli, A.R., Genovesi, P., Gentili, R., Lazzaro, L., Lonati, M., Lucchese, F., Mainetti, A., Mariotti, M., Minissale, P., Paura, B., Pellizzari, M., Perrino, E.V., Pirone, G., Poggio, L., Poldini, L., Poponessi, S., Prisco, I., Prosser, F., Puglisi, M., Rosati, L., Selvaggi, A., Sottovia, L., Spampinato, G., Stanisci, A., Stinca, A., Venanzoni, R., Lastrucci, L., 2020. A first checklist of the alien-dominated vegetation in Italy. Plant Sociol. 57, 29-54.

Vilà, M., Tessier, M., Suehs, C.M., Brundu, G., Carta, L., Galanidis, A., Lambdon, P., Manca, M., Medail, F., Moragues, E., Traveset, A., Troumbis, A.Y., Hulme, P.E., 2006. Local and regional assessments of the impacts of plant invaders on vegetation structure and soil properties of Mediterranean islands. J. Biogeogr. 33, 853-861. https://doi.org/10.1111/j.1365-2699.2005.01430.x.

Villa, P., Pinardi, M., Bolpagni, R., Gillier, J.-M., Zinke, P., Nedelcuţ, F., Bresciani, M., 2018. Assessing macrophyte seasonal dynamics using dense time series of medium resolution satellite data. Rem. Sens. Environ. 216, 230-244. https://doi.org/ 10.1016/j.rse.2018.06.048.

Villa, P., Pinardi, M., Tóth, V.R., Hunter, P.D., Bolpagni, R., Bresciani, M., 2017. Remote sensing of macrophyte morphological traits: implications for the management of shallow lakes. J. Limnol. https://doi.org/10.4081/jlimnol.2017.1629.

Vilà, M., Hulme, P.E., 2017. Impact of biological invasions on ecosystem services. Springer International Publishing. https://doi.org/10.1007/978-3-319-45121-3.

Vítková, M., Müllerová, J., Sádlo, J., Pergl, J., Pyšek, P., 2017. Black locust (Robinia pseudoacacia) beloved and despised: a story of an invasive tree in Central Europe. For. Ecol. Manag. 384, 287-302. https://doi.org/10.1016/j.foreco.2016.10.057.

Walker, K.J., Preston, C.D., Boon, C.R., 2009. Fifty years of change in an area of intensive agriculture: plant trait responses to habitat modification and conservation Bedfordshire, England. Biodivers. Conserv. 18, 3597-3613. https://doi.org/ 10.1007/s10531-009-9662-y.

Zedda, L., Cogoni, A., Flore, F., Brundu, G., 2010. Impacts of alien plants and man-made disturbance on soil-growing bryophyte and lichen diversity in coastal areas of Sardinia (Italy). Plant Biosystems - An International Journal Dealing with all Aspects of Plant Biology 144, 547-562. https://doi.org/10.1080/11263501003638604. 